\title{
FINANCIAL INCENTIVES FOR INCREASING WORK AND INCOME AMONG LOW-INCOME FAMILIES
}

\author{
Rebecca M. Blank \\ David Card \\ Philip K. Robins \\ Working Paper 6998 \\ http://www.nber.org/papers/w6998 \\ NATIONAL BUREAU OF ECONOMIC RESEARCH \\ 1050 Massachusetts Avenue \\ Cambridge, MA 02138 \\ March 1999
}

\begin{abstract}
Prepared for the Joint Center for Poverty Research Conference, "Labor Markets and Less Skilled Workers," November 5-6 1998. Conference attendees provided useful comments, as did Gordon Berlin, Ginger Knox, and Dan Rosenbaum. The views expressed in this paper are those of the authors and do not reflect those of the National Bureau of Economic Research or of any organization with which they may be affiliated.

( 1999 by Rebecca M. Blank, David Card, and Philip K. Robins. All rights reserved. Short sections of text, not to exceed two paragraphs, may be quoted without explicit permission provided that full credit, including $\left.{ }^{(}\right)$notice, is given to the source.
\end{abstract}


Financial Incentives for Increasing Work and

Income Among Low-Income Families

Rebecca M. Blank, David Card, and Philip K. Robins

NBER Working Paper No. 6998

March 1999

JEL No. I38, J22

\begin{abstract}
$\underline{\text { ABSTRACT }}$
This paper investigates the impact of financial incentive programs, which have become an increasingly common component of welfare programs. We review experimental evidence from several such programs. Financial incentive programs appear to increase work and raise income (lower poverty), but cost somewhat more than alternative welfare programs. In particular, windfall beneficiaries -- those who would have been working anyway -- can raise costs by participating in the program. Several existing programs limit this effect by targeting long-term welfare recipients or by limiting benefits to full-time workers. At the same time, because financial incentive programs transfer support to working low-income families, the increase in costs due to windfall beneficiaries makes these programs more effective at alleviating poverty and raising incomes. Evidence also indicates that combining financial incentive programs with job search and job support services can increase both employment and income gains. Non-experimental evidence from the Earned Income Tax Credit (EITC) and from state Temporary Assistance to Needy Families (TANF) programs with enhanced earnings disregards also suggests that these programs increase employment, and this evidence is consistent with the experimental evidence on the impact of financial incentive programs.
\end{abstract}

Rebecca M. Blank

Department of Economics

Northwestern University

Evanston, IL 60208

and NBER

rblank@nwu.edu

David Card

Department of Economics

University of California Berkeley

Berkeley, CA 94720-3880

and NBER

card@econ.berkeley.edu

Philip K. Robins

Department of Economics

University of Miami

Coral Gables, FL 33124-6550 


\section{$\underline{\text { I. Introduction }}$}

Policy makers in the United States and around the world have long struggled to accomplish at least three goals in the design of welfare programs: raise the living standards of low income families; encourage work and economic self-sufficiency; and keep government costs low. Many analysts have argued that these three goals are inherently inconsistent; some have even characterized the conflict between them as the "iron triangle" of welfare reform. Nevertheless, a number of programs have been initiated over the past five years that aim to accomplish all three goals through an innovative set of financial incentives, sometimes in combination with job-search assistance or other services. As yet, these new programs have received only limited attention from policy analysts, although they are being widely adopted by states in the wake of the recent welfare reform legislation. This paper provides an overview of the effects of these financial incentive programs, particularly focusing on work activity among welfare participants and low-income families.

From decade to decade, the emphasis behind changes in welfare programs has shifted. In the late 1960 s and early 1970 s, the anti-poverty objective came to the fore. In the early 1980s, cost reduction emerged as the dominant policy theme. Most recently, work and selfsufficiency have taken a center stage. At the same time, major Federal legislation in 1996 abolished the Aid to Families with Dependent Children (AFDC) entitlement program that had provided a framework for state cash assistance programs to low-income (and predominantly single-parent) families. AFDC was replaced with a new block grant -- the Temporary Assistance for Needy Families (TANF) program - that gives the states much greater leeway in designing their own TANF-funded welfare programs. In response, most states have introduced substantial changes to their welfare programs, with an emphasis on moving welfare recipients 
into work as rapidly as possible.

This new program design authority by states, along with an ongoing emphasis on work, has led to a renewed interest in the use of financial incentives to increase the work effort of welfare recipients and other low-income families. At the state level, legislators have placed a high priority on enhanced work incentives in their new TANF regulations: most states have eliminated the 100 percent earnings "tax" that characterized the federal AFDC program from 1982 to 1996 . At the same time, the Federal government has reinforced financial incentives by greatly expanding the Earned Income Tax Credit, which provides subsidies to low-wage workers. In addition, the high level of interest in welfare program design has produced a variety of pilot programs that have been rigorously evaluated, and which utilize financial incentives in innovative ways to increase work effort among low-income families. This paper combines information from all of these sources to evaluate the effectiveness of financial incentive programs.

While the "work" objective has clearly moved forward in the welfare policy agenda, the cost and the anti-poverty objectives have not been forgotten. Indeed, some of the renewed interest in financial incentives has been driven by the belief (or hope) that finely tuned financial incentive programs could increase work without a substantial increase in program costs. Preliminary results from a number of the pilot programs with formal evaluations indicate that they are able to increase overall family income and reduce poverty, but they also require greater resources, at least during the period for which evaluation results are available.

This paper begins with a brief theoretical overview of the issues surrounding financial incentives. We distinguish between two groups of low-income families potentially affected by 
an incentive program: current welfare recipients who might be incentivized by the program to increase work effort; and working non-recipients who could become "windfall beneficiaries" of a program reform and start collecting benefits. The costs, the labor supply effects, and the impact on family income of financial incentive programs depend crucially on the relative fractions of these two groups in the target population. As discussed below, an increased share of windfall beneficiaries increases cost and may reduce the aggregate employment gain, but it also increases the anti-poverty impact of the program. Many current financial incentive programs limit the number of windfall beneficiaries through various targeting rules and program restrictions. For example, eligibility might be limited to people who have already spent a waiting period on the regular welfare program, or incentive payments may be restricted to those who work full-time.

The third section of the paper summarizes the available evidence from recent experimental evaluations of financial incentive programs. Although many of the evaluations are still in-progress, preliminary findings from several different programs indicate that financial incentive programs can raise work effort among welfare recipients. The programs also have a significant anti-poverty effect. This is a striking result, and contrasts favorably with the results of earlier welfare reform experiments, such as the Negative Income Tax experiments, in which labor supply reductions among program beneficiaries led to a trade-off between income and work effort. In most cases, the gains in work effort and income in the recent experiments come at the expense of a modest increase in costs relative to an alternative welfare system without financial incentives.

The fourth section of the paper briefly examines some non-experimental evidence on 
the effects of the Earned Income Tax Credit (EITC), and on the enhanced earnings disregards that have been adopted in many state welfare systems. Again, the evidence points to a significant effect on the level of work activity among welfare recipients (and single mothers more generally). The final section of the paper concludes with some policy lessons and directions for further research.

Although discussed below, it is worth emphasizing at the outset three key differences between current financial incentive programs and the Negative Income Tax (NIT), popularized in a series of experiments in the 1970s (see Robins, 1985, for a summary of these experiments). We think the results from current financial incentive programs are more promising than the results often cited from the earlier NIT experiments. First, unlike the NIT experiments, current financial incentive programs are combined with work requirements. Most states are enacting financial incentive programs as part of a larger package of services that includes strong job search requirements and work demands on beneficiaries. Second, these programs are targeted to current welfare recipients, and are designed to discourage the entry of non-recipients. By comparison, the NIT programs were aimed at the entire lowincome population, and most of the disincentive effects of these programs arose because of labor supply reductions among families who were not already on welfare, but were windfall beneficiaries of the NIT. A third and related point is that the NIT experiments took place in an era of expanding "welfare rights," and were designed to test a universal public assistance program. Current financial incentive programs have a very different message, and are typically imbedded in programs where recipients are provided with programmatic and psychological encouragement to reduce their use of public assistance and become economically 
self-sufficient in the long run. This difference is particularly notable for financial incentive programs that are part of time-limited TANF programs.

\section{Theoretical Issues Underlying the Effectiveness of Financial Incentives}

Many of the conceptual issues underlying the role of financial incentives in increasing work and income among welfare recipients and other low income families can be illustrated in a simple graph like Figure 1. The horizontal axis on this graph represents hours of work by a single parent. ${ }^{1}$ We use a monthly time frame in our discussion, because welfare eligibility is determined on a month-by-month basis. The vertical axis represents monthly cash income. To begin our analysis, we assume that a parent has no income sources other than earnings or welfare, that she can freely choose her hours of work at a constant wage of \$w per hour, that a welfare grant of $\$ \mathrm{G}$ is available, and that the welfare program has a simple fixed earnings disregard of \$D per month, with no other benefits (such as housing vouchers). These assumptions generate a budget constraint that rises at rate $\mathrm{w}$ per hour for the first $\mathrm{l}^{\mathrm{p}}$ hours of work per month, where $h^{0}=\mathrm{D} / \mathrm{w}$ is the number of hours of work needed to just meet the disregard. Thereafter, until hours exceed the threshold $h^{1}=(G+D) / w$, the budget constraint is flat: additional earnings are "taxed" at a rate of 100 percent. Finally, for hours beyond $h^{1}$, the single parent is no longer eligible for welfare, and each additional hour of work generates $\$ \mathrm{w}$ in cash income. ${ }^{2}$

\footnotetext{
'We focus on single parent families throughout this section. In Section III we describe some findings that pertain to dual-parent families.

${ }^{2}$ For simplicity we ignore other income and payroll taxes. We also ignore Food Stamps, which are available to most AFDC recipients and which add resources to the basic grant, but also add complexity to the budget line.
} 
Figure 1 provides a stylized description of the Aid to Families with Dependent Children (AFDC) program as it existed from 1982 to 1996 . Although the basic features of this program were set by federal law, interstate differences in welfare benefit schedules, together with individual-specific differences in wages, generated wide variation in the locations of the "kink" points in the budget constraint. For example, $h^{t}$ was about 83 hours per month (19 hours per week) for a single mother with one child in California in 1996 who could earn $\$ 7.00$ per hour, and about 36 hours per month ( 8 hours per week) for a comparable mother in Arkansas. ${ }^{3}$

Two critical features of the AFDC budget constraint in Figure 1 are the "flat" range of cash income for hours between $\mathrm{h}^{0}$ and $\mathrm{h}^{1}$, and the absence of benefits for any single mother whose earnings exceed the relatively modest "breakeven" income level $\$ G+D .{ }^{4}$ The 100 percent implicit tax on earnings creates a substantial work disincentive for welfare participants: in the absence of work requirements, one would not expect to see welfare recipients earning more than the disregard amount. By the same token, the restriction of benefit eligibility to families who earn less than the breakeven income implies that the welfare system had a negligible anti-poverty effect on the working poor. ${ }^{5}$

In fact, the labor supply behavior and poverty outcomes of single mothers and their families in the 1980s and early 1990s are broadly consistent with these observations. For

\footnotetext{
${ }^{3}$ These calculations assume a disregard of $\$ 90$ per month -- the level available for work expenses, ignoring child care expense disregards.

${ }^{4}$ In states where the payment standard $(\mathrm{P})$ is higher than the maximum benefit level $(\mathrm{G})$, the breakeven income level is $\$ P+D$. In 1996 breakeven levels ranged from $\$ 254$ per month for a longer-term recipient in Alabama with two children (eligible for a grant of $\$ 164$ and a $\$ 90$ per month disregard) to $\$ 1118$ per month for a similar family in Alaska.

${ }^{5}$ In most states families hit the breakeven point before their income rose above the poverty line.
} 
example, tabulations of 1988-93 Current Population Survey data (reported in Section IV, below) reveal that only about 20 percent of single mothers who were on AFDC continuously during the year had any labor earnings. ${ }^{6}$ At the same time, the poverty rates of female-headed families averaged around 50 percent. $^{7}$ Poverty rates for families headed by working women were somewhat lower -- around 33 percent -- but these families still accounted for a sizeable fraction of the nation's poor population.

\section{A. Introducing Financial Incentives}

Many analysts have argued that a simple modification of the welfare system illustrated in Figure 1 could raise the employment rates of welfare recipients and supplement the incomes of the working poor. This modification -- lowering the implicit tax rate on earnings by disregarding a fraction of welfare recipients' earned income -- is the standard design of a negative income tax (NIT). The effect on the budget constraint of a single mother is illustrated in Figure 2. For simplicity, the basic welfare grant is assumed to remain at $\mathrm{G}$ and we ignore the previous "flat" disregard D. Now, however, each additional dollar of earnings reduces the grant by $\$ \mathrm{t}$, where $0<\mathrm{t}<1$, for earnings up to the breakeven level $\$ \mathrm{G} / \mathrm{t}$. Equivalently, a welfare recipient is allowed to disregard a fraction (1-t) of her earnings. This payment system can also be recast as an "earnings supplement": an individual who earns an amount $\$ y$ receives a supplementary check for a fraction $t$ of the difference between $\$ y$ and the breakeven earnings

\footnotetext{
${ }^{6}$ Data from an earnings subsidy experiment in Canada (the Self-Sufficiency Project, or SSP) also shows about a 20 percent employment rate among longer-term welfare recipients (at the baseline of the experiment). See Card and Robins (1988, Table 2).

${ }^{7}$ These are our own calculations rather than "official" poverty rates. See Section IV.
} 
level \$G/t.

A reduction of the implicit tax rate on welfare benefits has potentially important labor supply effects on four distinct subgroups of low-income people. First, the elimination of the "flat" segment of the budget constraint introduces an unambiguously positive work incentive for welfare recipients who were previously not working. Second, welfare benefits are raised and the implicit tax rate is lowered for people who were previously working and receiving welfare. Although at first glance one might not expect anyone to work if their earnings are taxed at $100 \%$, in reality there are always people in this situation. Working welfare recipients may be "in transition" from welfare to work, holding a part-time job with the intention of moving to full-time work in the near future. Alternatively, they may value some benefit of welfare participation (such as subsidized child care or housing) that is missing from the simplified budget analysis in Figure $2{ }^{8}$ For this group financial incentives have a mixed incentive effect, because they raise the marginal wage (from 0 to $w(1-t)$ ) while also raising incomes.

A third and potentially more important effect of financial incentives is to open up benefit eligibility to a subset of low-income workers who were not receiving welfare previously, but whose earnings are less than the new breakeven. The expansion of benefit eligibility to these "windfall beneficiaries" (those who were off welfare and working between $\mathrm{h}^{1}$ and $\mathrm{h}^{2}$ in the absence of incentives) has an unambiguously negative incentive effect on their

\footnotetext{
${ }^{8}$ Prior to expansions of the Medicaid program in the late 1980 s, low income families who moved off welfare were likely to lose medical coverage. Recent reforms have eliminated the link between Medicaid eligibility and welfare participation, at least for children. See Shore-Sheppard (1997) for a discussion of these changes and references to earlier studies.
} 
work effort, since it lowers the marginal wage rate (from $w$ to $w(1-t)$ ) while raising incomes. Finally, a fourth potential effect of a proportional earnings disregard is to induce some people who were previously working more than $\mathrm{h}^{2}$ hours per month under the old system to lower their hours and "opt in" to the welfare system. These people are also beneficiaries of a proportional disregard, although they are not directly identifiable prior to the introduction of the new system, because their earnings were above the new breakeven threshold. They are not windfall beneficiaries (by our definition) because they must change their behavior in order to trade income for greater leisure.

A reduction in the implicit tax rate on benefits with no change in the basic welfare grant unambiguously raises the cash incomes of non-working welfare recipients who are incentivized to work. It also raises the incomes of individuals who were previously working, but earning less than the new breakeven. For people who were working more than $\mathrm{h}^{2}$ hours but are incentivized to cut hours and "opt-in" to welfare, the reduction in the implicit tax rate lowers cash income. Provided that the opt-in group is relatively small, however, a proportional earnings disregard will raise overall cash incomes and may lower poverty, depending on where the breakeven point sits with regard to the poverty line.

This discussion suggests that the labor supply and anti-poverty effects of a proportional earnings disregard depend on two critical factors: the relative sizes of the four groups affected by the reform (non-working welfare recipients, working welfare recipients, non-recipients who are currently earning less than the new breakeven, and non-recipients who are currently

\footnotetext{
${ }^{9}$ Formally, we define windfall beneficiaries as people who would have been off welfare in the absence of a program change, and who become eligible for the program without changing their behavior. By this definition, people who were previously working and on welfare are not windfall beneficiaries.
} 
earning a little more than the new breakeven but will opt-in); and the magnitudes of the behavioral responses expected among each group. The sizes of the first three groups can be fairly easily forecast in any particular case by estimating the relative numbers of single parents already on welfare and either working or not, and the number who are off welfare but earning less than the new breakeven income level.

With respect to the fourth group, Ashenfelter (1983) used a conventional labor supply model to show that the expected number of "opt-ins" associated with the introduction of financial incentives is the fraction of people earning between $B$ and $B(1+g)$, where $B=G / t$ is the new breakeven income level, $\mathrm{g}=0.5 \epsilon^{\mathrm{c}} \mathrm{t}$, and $\epsilon^{\mathrm{c}}$ is the compensated elasticity of labor supply. ${ }^{10}$ The NIT experiments suggest that $\epsilon^{\mathrm{c}}$ is on the order of 0.15 for working single mothers (see Ashenfelter, 1983, and Robins, 1985). For example, in the case of a 50 percent implicit tax rate, the estimated fraction of "opt-ins" is the fraction of individuals earning from 100 to 104 percent of the new breakeven. The size of the "opt-in" group may be substantially smaller if there is significant "stigma" associated with welfare participation (Moffitt, 1983), or if there are other costs of being on welfare, such as the costs of applying or maintaining contact with case workers, or if it is difficult to make small hours reductions on jobs.

The magnitudes of the behavioral responses for the various groups are also potentially forecastable using estimates from the existing labor supply literature. The literature is most informative about the behavioral responses of the windfall beneficiaries who are off welfare and working prior to the change in the welfare system. For a windfall beneficiary who was

\footnotetext{
${ }^{10}$ Ashenfelter shows that the threshold income level for "opting-in" is $B /\left(1-0.5 \epsilon^{c} t\right)$. For reasonable values of the parameters this is approximately equal to the expression in the text.
} 
previously working $h$ hours per month $\left(\mathrm{h}^{1}<\mathrm{h}<\mathrm{h}^{2}\right)$ and earning a wage $\mathrm{w}$, a standard labor supply framework predicts a proportional labor supply reduction of approximately

$$
\Delta \mathrm{h} / \mathrm{h}=-\mathrm{t} \epsilon^{\mathrm{c}}-(\mathrm{G}-\mathrm{twh}) / \mathrm{wh} \times(1-\mathrm{m}),
$$

where $\epsilon^{c}$ is the compensated elasticity of labor supply and $m$ is the marginal propensity to buy goods out of additional income, rather than to reduce work and "buy" leisure (i.e., it is the fraction of each additional dollar of non-wage income that a person will devote to consumption versus increased leisure). The first term in this expression is the substitution effect, attributable to the reduction in the marginal wage by $\mathrm{t}$ percent, while the second is the income effect, attributable to the net earnings subsidy (G-twh). Assuming that $\epsilon^{c}$ is on the order of 0.15 and the marginal propensity to buy goods is roughly 0.85 , a windfall beneficiary who was previously earning 1.5 times the welfare grant might be expected to reduce labor supply by 10 percent in response to a program that introduces a 50 percent earnings disregard. ${ }^{11}$

As with the "opt-in" group, this calculation assumes a smooth adjustment, in which everybody below the new break-even level participates in the program. This behavioral response will be smaller if there is "stigma" or other costs associated with entering and staying on welfare, or if hours are constrained by employers and small reductions are difficult. Furthermore, most of the windfall beneficiary group is likely to be eligible for relatively small benefit payments, and evidence suggests that eligible persons with low benefits are least likely to participate in public assistance programs (Blank and Ruggles, 1996). For all these reasons, the above calculation should be viewed as a maximal possible effect.

\footnotetext{
${ }^{11}$ The labor supply changes for the "opt-in" group can be calculated using this same formula, and noting that for those who opt-in, the net subsidy is approximately 0.
} 
The conventional labor supply literature is less informative about the magnitude of the behavioral responses among single parents who were previously on welfare and not working, or working only a little. Fortunately, recent social experiments offering earnings subsidies or enhanced earnings disregards to welfare recipients provide direct and highly credible evidence on this issue. In the next section we review this evidence and try to draw some conclusions about the expected increases in work effort and incomes among former welfare recipients who are presented with financial incentives to work.

\section{B. Modified Financial Incentive Programs}

A simple proportional earnings disregard program (such as in Figure 2) creates financial incentives for non-working welfare recipients to enter the labor market, but also creates incentives for current non-recipients (the windfall group) to reduce their work effort. Indeed, one of the key lessons from the NIT experiments conducted in the 1970s (Robins, 1985 ) is that the latter disincentive effects can be non-trivial. Particularly under a NIT-like universal welfare system, any expansion of benefit eligibility to current non-recipients will increase government costs and increase the number of welfare recipients. In an era of tight government budgets and strong public distaste for "welfare," policies that raise costs or increase the size of the recipient population are unlikely to muster political support. The welfare reforms of the early 1980 s which eliminated financial incentives for work by imposing a 100 percent tax rate on the earnings of AFDC benefit recipients were presumably motivated by these concerns.

The current popularity of financial incentive programs is due to the fact that there have 
been a variety of responses to the challenge of designing financial incentive programs that raise the labor supply and incomes of welfare recipients (or low-income families, more generally) while preventing an expansion of welfare rolls and costs. Most importantly, the current welfare programs (of which financial incentives are only one part) are quite different from a universal minimum cash benefit program. They include strong work requirements, and often other behavioral requirements as well. These requirements presumably reduce the incentives for windfall beneficiaries to enter the program, and reinforce the incentives for participants to increase their work effort.

Another response is the creation of financial incentives outside the traditional welfare system. The Earned Income Tax Credit (EITC) works in this manner. As we discuss in more detail in Section IV, the EITC offers a (nonlinear) earnings supplement; in its phase-out range it is similar to a variable earnings disregard. ${ }^{12}$ Politically, the EITC program is not viewed as "welfare," so the costs of the program and the size of the recipient population do not attract the same attention as they presumably would if the EITC were "rolled in" to the TANF program.

A third response is to target the financial incentives at particular groups of poor people. For example, the Self Sufficiency Project (SSP) taking place in Canada offers a three-year earnings supplement (equivalent to an enhanced earnings disregard) to individuals who have been on welfare for at least a year. Since most long-term welfare recipients will remain on welfare in the near future, there are very few windfall beneficiaries of the program in the

\footnotetext{
${ }^{12}$ The tax credits provided by the EITC are the same in all states. Thus, the interaction of the EITC and the state TANF program creates different relative incentives for work in different states, depending on the features of the TANF program in a particular state.
} 
period immediately following eligibility determination. Moreover, anyone who wants to become eligible for the earnings supplement has to enter welfare and remain on (under program rules very similar to the AFDC system) for a full year. As we discuss in more detail in Section III, the results of a randomized evaluation of the welfare-leaving rates of new applicants (Card, Robins and Lin, 1997) suggests that this is an effective entry barrier greatly limiting the size of the windfall population.

Targeting of financial incentives to longer-term recipients (or to groups who pass other hurdles) presents a number of difficulties, however. First, it may be viewed as inequitable, since a person who never enters welfare is "penalized" relative to one who decides to go on welfare for some time and then return to work. Targeting also limits the scope for achieving an anti-poverty objective by limiting the program's availability. Second, and perhaps more importantly, targeting can only screen out windfall beneficiaries to the extent that behavior is static. In reality, any group of longer-term welfare recipients contains some people who will eventually begin working and move off welfare, even if none of them are working at the time they pass the targeting hurdle. In the control group of the SSP experiment, for example, about 15 percent of single parents who had been on welfare for over a year were off welfare and working within 18 months (Lin et al, 1998, Table 1). Many of these individuals would be windfall beneficiaries of SSP in the second year of the program. A fixed targeting hurdle cannot permanently distinguish between windfall beneficiaries and non-windfall beneficiaries if the behavior of the targeted population is shifting over time.

A fourth response to the challenge posed by the behavior of the windfall beneficiaries in a financial incentive scheme is to restrict eligibility to full time workers, or to provide strong 
nonfinancial incentives for people to work full-time. The SSP program, for example, requires individuals to work at least 30 hours per week in order to receive the earnings supplement. ${ }^{13}$ Figure 3 illustrates the budget constraint under such a system, assuming that benefits are only available to those who work at least $\mathrm{h}^{*}$ hours. A full-time hours of work restriction has a number of effects relative to an unrestricted financial incentive plan. First, some people who would be windfall beneficiaries in the absence of an hours restriction -- those who were off welfare and working between $\mathrm{h}^{1}$ and $\mathrm{h}^{*}$ hours prior to the introduction of financial incentives -are no longer eligible for benefits without increasing their work effort. Second, other windfall beneficiaries who were off welfare and working more than $\mathrm{h}^{*}$ hours in the absence of financial incentives can no longer reduce their hours below $h^{*}$ and still receive benefits. Both of these effects reduce the scope for any negative labor supply responses to financial incentives, and also reduce the costs of the program, since benefit payments are lower for people who work longer hours.

Limiting eligibility to full-time workers also presumably affects the behavior of the non-windfall group (people who were on welfare prior to the introduction of financial incentives). For this group, however, the net effects on labor supply and earnings are unclear. Some people who would have moved from non-employment to part-time work under an unrestricted financial incentive program may decide to move to full-time employment. Others may find full-time work infeasible or unavailable, and may therefore remain unemployed, even though they would have worked part-time work if the budget constraint were the same as in

\footnotetext{
${ }^{13}$ In the Minnesota Family Investment Program (MFIP), individuals who are eligible for the program's earnings supplement are required to undergo "case management" if they work less than 30 hours per week.
} 
Figure 2 .

These considerations suggest that a full-time hours limitation is likely to reduce the size of the windfall group and reduce the magnitude of any negative labor supply responses for this group, but it may also limit the range of positive labor supply responses among the nonwindfall group. On net then, the introduction of a full-time hours restriction can probably prevent a financial incentive program from reducing labor supply, but it may or may not raise the relative fraction of incentivized versus windfall beneficiaries. This ratio is a critical determinant of the social cost-benefit ratio for a financial incentive program, since windfall beneficiaries at best contribute as much to benefits as to costs, whereas incentivized beneficiaries contribute more to social benefits than to social costs. ${ }^{14}$

\section{Experimental Evidence on the Effects of Financial Incentive Programs}

In this section we review some of the recent evidence on the effects of financial incentives for work among welfare recipients and other low income families, based on a series of randomized social experiments that have been conducted to evaluate financial incentives. Some of these experiments involve program innovations that work within the existing welfare system, such as the introduction of a proportional earnings disregard. Other experiments operate outside the existing welfare system, offering low-income families an alternative income support program that is administered by specialized staff through their own offices. All but

\footnotetext{
${ }^{14}$ If windfall beneficiaries' labor supply is constant, then each dollar of benefits paid raises their income by $\$ 1$, and social benefits are equal to social costs. If their labor supply falls, however, then each dollar of benefits results in a socially inefficient reduction in work effort, implying that social benefits are less than social costs. On the other hand, for incentivized beneficiaries, any increase in earnings is a net social gain.
} 
one of these experiments have been conducted on samples of current welfare recipients and fill a very important gap in our knowledge about the effects of financial incentive programs on the large numbers of current welfare participants -- the majority of whom are not working. The experimental evaluations provide only limited evidence on program effects for non-welfare recipients. We noted in the last section that the existing labor supply literature (including the NIT experiments of the 1970 s) provides a relatively strong foundation for predicting the effects of financial incentive programs on current non-recipients for programs that are less targeted.

In the next section we briefly summarize some non-experimental evidence on the effects of two important financial incentive programs that are now affecting welfare recipients and other low income families throughout the U.S.: the EITC program, and the enhanced earnings disregards that have been introduced in the TANF programs of most states. Although the nonexperimental evidence must be viewed with caution, we believe that it provides a valuable complement to the results in this section from the more limited experimental programs.

\section{A. Financial Incentive Programs with Experimental Evaluation}

Table 1 describes the features of 7 recent or ongoing financial incentive programs that are being evaluated by random assignment methods. Panel A of Table 1 describes 4 programs that operate within the existing welfare systems of the program sites: the Minnesota Family Investment Program (MFIP); the Welfare Restructuring Program (WRP) in Vermont; the Family Transition Program (FTP) in Florida; and the Jobs First (JF) program in Connecticut. All four of these programs are testing a combination of financial incentives and non-financial incentives (such as job-search assistance or case management) on samples of current welfare 
recipients. Only the MFIP evaluation is designed to distinguish the effects of financial incentives from the potential effects of these additional features. This is accomplished by randomly assigning the people who participated in the MFIP evaluation into three groups: one treatment group receiving the standard MFIP program which offered financial incentives plus employment and training services, a second treatment group receiving financial incentives only; and a third control group subject to the rules of the existing Minnesota AFDC system. ${ }^{15}$

The financial incentives in MFIP consist of two main features: an increase in the basic welfare grant by 20 percent if the welfare recipient becomes employed (subject to a maximum equal to the regular welfare grant); and a reduction in the implicit tax rate on earnings to 62 percent (i.e., a 38 percent earnings disregard). ${ }^{16}$ In addition, MFIP provides a "cash-out" of food stamp benefits. The budget constraints under the MFIP treatment and the control environment are shown in Figure 4, for a single mother with one child who earns $\$ 5.00$ per hour. The former is labeled "Earnings + MFIP" while the latter is labeled "Earnings + AFDC + Food Stamps" to reflect the cash-out of food stamps. Figure 4 suggests that MFIP provides modest financial incentives for work among low-wage welfare recipients throughout a wide range of weekly hours.

The financial incentives being tested in the other programs summarized in Panel A of Table 1 range from an earnings disregard of $\$ 150$ plus 25 percent of earnings in the Vermont WRP to a 100 percent earnings disregard for earnings below the poverty level in the

\footnotetext{
${ }^{15}$ MFIP enrolled two types of welfare recipients, new applicants for welfare and long-term recipients who had been receiving welfare for at least two years. In this paper, we focus only on the long-term recipient group.

${ }^{16}$ When MFIP was introduced in 1994, the implicit tax rate on earnings in the Minnesota AFDC program was 100 percent. In 1996 the 38 percent earnings disregard was implemented for the entire state TANF program.
} 
Connecticut Jobs First program. The Florida FTP is in the middle in terms of generosity, and is broadly representative of the incentive programs that have been adopted throughout the country as part of states' TANF-funded programs. FTP replaces the standard $\$ 90$ per month flat disregard in the pre-1996 AFDC program (for single parents who have been on welfare over a year) with a $\$ 200$ flat disregard and a proportional disregard of 50 percent of earnings above $\$ 200$.

A number of more innovative financial incentive programs operate outside (or alongside) the existing welfare system. Panel B summarizes three of these programs: the Self Sufficiency Project (SSP) in British Columbia and New Brunswick, Canada; the New Hope project in Milwaukee, Wisconsin; and the Child Assistance Program (CAP) that operated in New York state in the early 1990s. Like the programs in Panel A, eligibility for the SSP and CAP demonstrations was limited to welfare recipients. ${ }^{17}$ In contrast, the New Hope program enrolled a broader group of low-income families, including both current welfare recipients and non-recipients.

In comparison to the programs in Panel A, most of which provide marginal changes to the current welfare system, two of the programs in Panel B are markedly different. Both SSP and New Hope operate entirely outside of the welfare system. In addition to financial incentives, the New Hope program includes a wide range of other features, including jobsearch assistance and temporary job placements for those unsuccessful in finding work on their

\footnotetext{
${ }^{17}$ The SSP demonstration includes two main components: one experiment utilizing a group of single parents who had been on welfare for at least a year in New Brunswick and British Columbia (comparable to the eligibility rules for MFIP); and a second experiment conducted on a group of new welfare applicants in British Columbia. We focus mainly on the former.
} 
own. The basic SSP program, in contrast, is a pure financial incentive that provides very generous subsidies for up to three years for those who work full time. The SSP demonstration includes a small experiment (known as SSP Plus and discussed below) that offers job search assistance in addition to the financial incentive package.

Both SSP and New Hope impose a minimum hours requirement. In each case, individuals must work 30 hours per week or more to become eligible for program payments. Figures $5 \mathrm{a}$ and $5 \mathrm{~b}$ illustrate the budget constraints for SSP and New Hope, for a single mother with one child who can earn $\$ 5 /$ hour in the respective program sites. ${ }^{18}$

The third program in Panel B of Table 1, the New York Child Assistance Program (CAP), does not impose a minimum hours requirement, but rather combines a proportional earnings disregard (with two disregard rates) and a reduced basic welfare grant. ${ }^{19}$ This combination of features "tilts" the program budget constraint, as illustrated in Figure 6. As we noted in Section II, the specific "kink points" of the budget constraint under AFDC and a proportional earnings disregard vary with the hourly wage. At an hourly wage of $\$ 5$ (Figure 6a), CAP dominates welfare after about 15 hours of work per week. At an hourly wage of $\$ 7$ (Figure 6b) CAP dominates welfare after about 11 hours per week.

Of all the financial incentive programs being tested or in operation, SSP is the most

\footnotetext{
${ }^{18}$ The control environments in SSP and New Hope are the respective welfare systems of the sites. The welfare systems in British Columbia and New Brunswick are similar to the pre-1996 AFDC systems in Wisconsin and other states, in that they set a basic welfare grant that varies with family size, offer a modest earnings disregard, and have a $100 \%$ tax rate on earnings above the disregard. SSP program benefits vary with earnings but not with family size, whereas New Hope benefits include a basic supplement and a child allowance. Figure $5 \mathrm{~b}$ graphs the New Hope budget constraint with and without this allowance.

${ }^{19}$ The CAP program was patterned after the child support assurance system developed by Garfinkel, et. al. (1990). Single mothers could only receive CAP payments if they had child support court orders. See Hamilton, et. al. (1996) for a description of CAP.
} 
generous. At 30 hours of work per week, annual SSP payments for a single parent earning the minimum wage in New Brunswick are about $\$ 5,600$ ( $\$ 7,200$ in Canadian dollars) higher than the payments the same person could receive from the regular welfare system. By contrast, at 30 hours per week the difference in payments between MFIP and the regular Minnesota welfare system is about $\$ 3,300$ for a single mother earning $\$ 5$ per hour. ${ }^{20}$ Similar calculations for New Hope and CAP show differentials of $\$ 3,500^{21}$ and $\$ 2,600^{22}$, respectively. Thus, SSP would be expected to have the largest effects on work of all of these programs. Although these simple generosity calculations do not take into account the complex interactions of the various programs with other tax and transfer programs, we believe that a full accounting of these interactions would not change the relative ranking of the programs' generosity.

\section{B. Effects of Financial Incentives on Employment and Earnings}

Each of the financial incentive programs described in Table 1 would be expected to increase employment and earnings of welfare recipients -- at least for the majority of recipients who would not be working in the absence of incentives. The magnitude of the effects depends on how a given program alters the budget constraint. In the cases of SSP and New Hope, for

\footnotetext{
${ }^{20}$ The maximum MFIP subsidy is $\$ 3340$ (per year).

${ }^{21}$ This calculation uses a wage of $\$ 5.00$ per hour, close to the minimum wage when New Hope began operating. At this wage, the maximum subsidy under New Hope is $\$ 3,721$ and occurs at 33 hours of work per week.

${ }^{22}$ The maximum subsidy under CAP for a person earning $\$ 5$ per hour is $\$ 3,250$ and occurs at 34 hours of work per week.
} 
example, only employment at 30 hours of work per week or more is expected to increase. ${ }^{23}$ The other programs might be expected to lead to some increase in part-time employment as well.

The effects on former welfare recipients who would be working in the absence of incentives are less clear. CAP and MFIP provide ambiguous incentives for people who would be working modest amounts in the absence of incentives, since both programs offer higher marginal wages and higher total incomes for people working less than 20 or 30 hours (i.e., they have offsetting income and substitution effects in this range). On the other hand, the hours restrictions in New Hope and SSP provide positive work incentives for people who might have otherwise worked less than 30 hours per week.

All the programs provide a disincentive for work among former welfare recipients who would have moved off welfare at some point during the demonstration period (i.e., the windfall beneficiaries). The range of work reductions is limited by the 30 hour requirements of SSP and New Hope, but such negative labor supply effects would be expected to some extent in all the programs.

It is important to keep in mind that all of the experimental demonstrations except New Hope utilize samples of current welfare recipients. Thus, the demonstration samples do not include as many windfall beneficiaries as might become eligible for payments if the financial incentive package were adopted as a general welfare system. For this reason, the earnings and hours gains measured in the demonstrations probably represent upper bounds on the impacts

\footnotetext{
${ }^{23}$ In fact, the incidence of employment at less than 30 hours is expected to decrease under SSP and New Hope because persons who would normally work part-time would be expected to increase hours to meet the program eligibility requirement of 30 hours of work per week (see Card and Robins, 1988, and Lin et al., 1998).
} 
that would be expected if the same incentive programs were adopted more generally. Moreover, measured reductions in caseloads or lower benefit payments in the demonstrations do not include increases in caseloads and payments to windfall beneficiaries who were not on welfare initially.

Table 2 presents experimentally-based estimates of the employment and earnings impacts of four financial incentive programs: SSP, CAP, MFIP, and FTP ${ }^{24}$ Except for FTP, the pure effects of the financial incentive component can be identified. For comparability, all the estimates are presented in 1997 U.S. dollars. The details of the data and time periods covered by the individual programs are presented in the table. All four programs had a statistically significant positive effect on the employment rate, ranging from a 2.8 percentage point increase in CAP to an 11.8 percentage point increase in SSP. The relatively large impact of SSP -- the most generous of the four programs -- is consistent with the hypothesis that larger financial incentives generate larger employment effects.

The impact of financial incentives on full-time employment is available for three of the experiments. Again, the impact is largest for SSP, where the full-time employment rate more than doubles. This may not be too surprising, given the generosity of SSP and the restriction of SSP benefits to full-time workers. In fact, the effect on full-time employment for SSP is larger than the effect on overall employment, indicating that the program reduced part-time employment.

In contrast to SSP, neither FTP nor the MFIP "financial incentives only" experimental

\footnotetext{
${ }^{24}$ The MFIP results in Tables 2, 3, and 5 are based on the experimental subgroup that received financial incentives only. Findings from evaluations of the Connecticut Jobs First program, the Vermont WRP, and New Hope were not yet available at the time this paper was completed.
} 
group has a full-time work requirement. The predicted effect of these programs on full-time employment is ambiguous: some people who would otherwise work low hours might respond to these programs by raising hours, while others who would have worked full-time in the absence of the programs might respond by cutting hours. ${ }^{25}$ Perhaps reflecting the importance of the latter subgroup's reactions, MFIP had a small (statistically insignificant) negative effect on full-time employment. On the other hand, the FTP program had a modest positive impact on full-time employment.

Except for MFIP, all the programs also increased earnings. The insignificant effect on earnings in MFIP may seem somewhat puzzling, since the program raised the fraction of people with any employment. One interpretation of the MFIP results is that the program had a relatively larger windfall beneficiary group, or larger negative incentive effects on the windfall beneficiaries, than the other programs, and that the negative incentive effects on the windfall groups offset positive effects on non-windfall recipients. ${ }^{26}$

To summarize, the experimental evidence indicates that financial incentive programs can increase employment among welfare recipients, although the employment effects seem to depend on the program design. With the exception of SSP, none of the programs that have been tested experimentally offer large financial incentives for increased work effort, and the resulting employment effects are modest. SSP offers relatively generous financial incentives,

\footnotetext{
${ }^{25}$ For example, in Figure 4, people who would have worked over 30 hours per week in the absence of MFIP face a lower marginal wage and higher income under the program, and might be expected to cut hours.

${ }^{26}$ Preliminary results for a later period are available for MFIP and suggest that the employment effect of the program disappears. This is consistent with the notion that the size of the windfall beneficiary group rises over time.
} 
and seems to have generated fairly large employment effects. Other key features of SSP, such as its targeting to relatively long-term welfare recipients and its full-time hours restriction, may also account for some of its larger impact.

\section{Effects on Receipt of Cash Transfers}

If financial incentive programs are to be politically palatable, they cannot lead to large increases in the number of people receiving cash assistance (i.e., the welfare caseload) or in the overall cost of welfare programs. A goal of no increase in the caseload is virtually impossible to meet for a financial incentive program, at least in the short run. This is because financial incentive plans, by their nature, extend the availability of cash benefits to a larger subset of the population. A goal of reducing (or at least not increasing) the overall cost of cash benefit programs is perhaps more feasible. Many financial incentive programs (e.g., FTP, MFIP, and CAP) have the property that each non-working welfare recipient who is incentivized to work reduces average benefit payments. Potential cost savings for nonworkers who enter employment may offset the increased costs associated with extending eligibility to previously working low-income families -- the windfall beneficiaries.

Table 3 shows the effects of SSP and MFIP on the fractions of people receiving cash transfers and on the average (per capita) value of cash transfers. Consider first the programs' effects on the cash assistance caseload. The excess fraction of the program group who receives cash assistance (relative to the controls) is an estimate of the size of the windfall beneficiary group. To see this, observe that someone who is incentivized by a program like SSP to leave welfare and enter full time work will reduce the regular welfare caseload by 1 and increase the 
SSP benefit role by 1 , with no net change in caseloads. There are also some people who were previously on welfare and working full time: these people also move from welfare to SSP with no change in the caseload. ${ }^{27}$ Finally, there is a group of windfall beneficiaries who would have been off welfare and working full time in the absence of SSP. These people move onto SSP with no reduction in the welfare caseload, implying a total increase in the fraction of people receiving some form of cash benefits. A similar argument applies to a program like MFIP that operates inside the regular welfare system.

Next consider the programs' effects on average cash assistance payments. Because SSP combines a reduction in the implicit earnings tax with what amounts to a rise in the basic welfare grant, the program does not necessarily reduce benefit payments, even to people who move from non-work to work. (This feature underscores the relative generosity of SSP compared to most financial incentive programs). In New Brunswick, for example, a single mother who does not work receives a typical annual welfare benefit of about $\$ 6,750$ (\$US). If she finds a full-time job and leaves welfare, she receives an SSP payment of about $\$ 8,350$ (\$US), leading to an increase of about $\$ 1,600$ in cash benefit costs. The MFIP program, by comparison, adjusts the earnings disregard without raising the basic welfare grant (as in Figure 2). Therefore, any person who moves from non-work to work lowers benefit costs. ${ }^{28}$ Even under MFIP, however, program costs will likely rise for people who would have been on

\footnotetext{
${ }^{27}$ Because the fraction of people who work full time and remain on welfare is small, this group is relatively small. Only 6.6 percent of Income Assistance recipients who became eligible for the SSP program were employed full time.

${ }^{28}$ For example, a single mother who does not work receives an annual welfare grant (AFDC plus Food Stamps) of about $\$ 9,200$. If she finds a full-time job in response to the MFIP financial incentive, she receives a payment of $\$ 6,200$-- a savings of about $\$ 3,000$.
} 
welfare and working part-time in the absence of incentives. ${ }^{29}$

Examination of Table 3 shows that both SSP and MFIP increased the cash benefit caseload and total benefit costs. In SSP, the fraction of people receiving cash assistance increased by 6.9 percentage points and the amount of cash assistance increased by $\$ 897$. In MFIP, the receipt of cash assistance increased by 7.1 percentage points and the amount of cash assistance increased by $\$ 1,198 .^{30}$ Thus, both SSP and MFIP provided benefits to about 7 percent of their respective experimental populations who would have been off welfare in the absence of an incentive program. For SSP, it is possible to estimate the fraction of windfall beneficiaries among all those who received SSP payments. In the 5th and 6th quarters of the SSP experiment, about 22 percent of the program group received SSP payments. Thus, about one-third (7/22) of SSP recipients are windfall beneficiaries -- people who would have left welfare and worked full time regardless of the program.

In light of the critical importance of windfall beneficiaries to the costs of a financial incentive program, it is interesting to consider how the fraction of windfall recipients varies across subgroups of participants in any particular program. For programs like SSP or New Hope that operate outside the regular welfare system and have a full-time eligibility restriction, one can estimate the fraction of windfall beneficiaries in several different ways. Table 4 shows

\footnotetext{
${ }^{29}$ Consider the simplified financial incentive scheme discussed in Section II, which replaces a $100 \%$ earnings tax with an implicit tax of $t$. A person who works $h_{0}$ hours under the old system receives a benefit of $\mathrm{G}-\mathrm{wh}_{0}$. If that person works $h_{1}$ under the incentive program, her benefit payment is $G-w h_{1} t$. The change in benefit payments is $w\left(h_{0}-h_{1} t\right)$ which is positive if $h_{1} / h_{0}<1 / t$. This is likely to be true for people with higher values of $h_{0}$.

${ }^{30}$ The other two programs, CAP and FTP, both led to statistically insignificant reductions in receipt of cash assistance, but because these programs tested other features in addition to financial incentives, it is not clear what caused the reductions.
} 
estimates of the fraction of windfall beneficiaries across subgroups of the SSP experiment, based on the difference between the fraction of the treatment group who received SSP payments and the program impact on the full-time employment rate. To understand these estimates, note that the program impact on the full-time employment rate is an estimate of the fraction of people incentivized by the program. Any difference between this number and the fraction of the program group who receive SSP payments represents an estimate of fraction that are windfall beneficiaries. ${ }^{31}$

Inspection of the data in Table 4 shows that the SSP participation rate (column 1 of the table) varies far more across subgroups than the SSP impact on full-time employment (column 4). This reflects large differences in the full-time employment rate in the absence of the program, as estimated by the behavior of the control group. Thus, the estimated fraction of windfall beneficiaries among all SSP participants varies dramatically by subgroup. Across subgroups defined by employment status at the start of the experiment, the fraction of windfall recipients ranges from less than 4 percent for those not in the labor force at the start of the program, to 76 percent for those employed full-time at the start of the program. Across training categories, the relative fraction of windfall recipients ranges from 23 percent for those without a training diploma to 50 percent among those with a training diploma. Similarly, the fraction of windfall beneficiaries is higher for those with a high school diploma than those without. These patterns suggest that the fraction of windfall participants might be reduced (and

\footnotetext{
${ }^{31}$ See footnote in Table 4 for the precise formula. Notice that similar estimates cannot be derived for a program like MFIP, because in the absence of an hours eligibility standard there is no obvious way to estimate the fraction of program participants incentivized by the program, nor is there any way to separate program recipients from other welfare recipients.
} 
program costs potentially lowered) by targeting less-educated subgroups of welfare recipients who are not already working.

\section{Effects on Income and Poverty}

One of the important features of financial incentive programs is their potential antipoverty effect -- particularly on the working poor. Given an anti-poverty objective, the presence of windfall beneficiaries is not an undesirable feature of a financial incentive program, because windfall recipients are low-income workers. Table 5 shows the impact of SSP and MFIP on family income and poverty. In both programs, income increased more than earnings, and the poverty rate was reduced significantly.

These results on income and poverty are worth emphasizing because they demonstrate the potential for financial incentive programs to reduce poverty. This is in contrast to many welfare-to-work programs of the 1980s and 1990s that increased earnings, but had little effect on family income or poverty (Gueron and Pauly, 1991). It is also in contrast to the negative income tax programs of the 1970 s that increased family income, but reduced earnings, leading to small income gains and very modest reductions in poverty (Keeley et al., 1978).

\section{E. Effects of Non-financial Program Features}

The evidence presented so far seems to indicate that carefully targeted financial incentive programs can raise work effort and improve the living standards of welfare recipients, albeit with some increase in program costs. Nonetheless, many analysts have argued that financial incentive programs can be made more effective and less costly by 
combining incentives with a variety of case management services, such as job search assistance. Both the SSP and MFIP experiments incorporate formal mechanisms to test this conjecture. SSP created an additional treatment group that was provided both financial incentives and additional services; MFIP added a "financial incentives only" experimental group to compare with the basic MFIP treatment that included both financial incentives and employment services. In this section we review the evidence on the efficacy of these additional services.

In SSP, the services treatment (known as SSP Plus) consisted of access to a "job coach" who helped with preparation of job resumes, guided participation in job clubs, provided job leads, offered counseling and encouragement on the value of employment, and provided referrals to community-based employment and training services. In MFIP, employment and training services ("case management") were provided to all welfare recipients who were not working at least 30 hours per week (20 hours per week for those with young children). These included job search assistance, short-term training, and educational activities, with a strong focus on entering employment quickly (Miller et al., 1997). Unlike SSP, the services in MFIP were mandatory: people who failed to comply with the participation mandate were subject to a 10 percent reduction in their monthly welfare payments.

Table 6 shows the incremental effects on employment and earnings of adding services to the financial incentives components of the SSP and MFIP programs. In both cases, services led to larger impacts on employment. In SSP, the employment impact increased by 6.9 
percentage points, from 8.6 to 15.5 percent. ${ }^{32}$ In MFIP, the employment impact increased by 9.7 percentage points, from 5.9 to 15.6 percent. In both SSP and MFIP, the employment rate for those receiving incentives plus services was close to 50 percent, which is very high for a sample of long-term welfare recipients. The incremental impacts on full-time employment are slightly positive (and statistically significant) in SSP, but are substantially larger for MFIP.

The modest impact of SSP Plus on full-time employment is puzzling, given the large overall effect of the program on employment, and may be due to two reasons. First, the work requirement in SSP is part of the financial incentives program. In contrast, the work "requirement" in MFIP occurs because job services are mandatory for those not working fulltime. This may explain why MFIP shows larger services impacts, while SSP shows larger financial incentive impacts. Second, SSP eligibility is predicated on holding a full-time job (or combination of jobs). Quets et al. (1999, forthcoming) show that although there was a significant effect on full-time employment in the early months of the SSP Plus demonstration, the impact faded over time. They conjecture that some of the people who were incentivized by SSP Plus tried hard to gain employment but were unable to sustain full-time work over the long run, leading to larger impacts on employment than full-time employment. ${ }^{33}$

In both SSP and MFIP, the inclusion of services also increased the earnings impacts.

\footnotetext{
${ }^{32}$ The SSP Plus impacts reported here are raw treatment-control differences and are based on small samples (roughly 250 people in each treatment group and in the control group). Regression-adjusted impact estimates, which control for differences in observable characteristics across the groups, show generally similar, but somewhat smaller, incremental impacts of services. In view of this, the SSP Plus findings must be viewed with some caution.

${ }^{33}$ They also find that the SSP Plus impacts are smaller when allowance is made for minor differences in the characteristics of the treatment and control groups in the experiment.
} 
In SSP, the availability of services doubled the earnings impact from $\$ 518$ to $\$ 1,113$ per month. In MFIP, the entire earnings impact of $\$ 1,013$ resulted from the provision of services: financial incentives alone had no impact on earnings.

The provision of job-coaching and case-management services is not costless, but seems to have enhanced the labor market impacts of SSP and MFIP. A perhaps equally important issue is whether services had any impact on benefit recipiency rates and program costs. Some evidence on this is provided in Table 7, where the incremental impacts of services on receipt of cash assistance are presented for SSP and MFIP. In both programs, the addition of services reduced the fraction of participants receiving cash assistance. In MFIP, the addition of services also lowered total benefit costs relative to financial incentives alone. In SSP, however, there were no net savings in total cash benefit costs relative to the financial incentive alone. The results on the marginal impact of services thus seem to vary somewhat between SSP and MFIP. Whether this is attributable to the differences between a voluntary versus mandatory service package, to the nature of the services, or to the way in which the work requirement is imbedded in these two programs (as discussed above), is unclear.

\section{F. Entry Effects}

A final issue raised by the recent experiments on financial incentives is whether the evaluations understate the costs of financial incentives because they fail to account for the presence of non-welfare recipients who are potentially eligible for benefits. All of the evaluations (other than the New Hope experiment, whose results are not yet available) are based on samples of welfare recipients. By raising the breakeven income level for program 
eligibility above the breakeven level of the current welfare program, however, financial incentive programs are likely to induce some additional low-income families to enter the welfare system, adding to the numbers of windfall beneficiaries. Such potential "entry effects" could raise the actual cost of any permanently implemented program far above the cost measured in the experimental evaluations. ${ }^{34}$ One response to the problem of entry effects is to create entry barriers. In SSP, this barrier is a requirement that single parents must remain on welfare for at least a year prior to becoming eligible for SSP. A one year "waiting period" precludes the natural response of low-income families to an unrestricted negative income tax, which is to apply for the program whenever their income falls below the breakeven of the program (or below a slightly higher threshold, as discussed in Section II).

The SSP demonstration includes a separate experiment -- described in Card, Robins, and Lin (1997) -- specifically designed to measure whether the one year waiting period is long enough to prevent new entrants to the welfare system who would otherwise leave welfare within a year from prolonging their stay in order to become eligible for the program. The experiment does not directly address the possibility that SSP might lead some people to apply for welfare who would otherwise never enter the system. The experimental findings indicate that about 3 percent of new welfare applicants who are informed of SSP extend their stay on income assistance for at least a year, over and above the fraction (roughly 50 percent) who would normally stay on welfare for 12 months or more. This estimate suggests that although

\footnotetext{
${ }^{34}$ Moffitt (1996) emphasizes the potential importance of entry effects associated with the provision of training services. In a review of nonexperimental studies of entry effects for government training programs, Friedlander, Greenberg, and Robins (1997) find the evidence for entry effects to be inconclusive.
} 
entry effects in SSP cannot be ignored, their impact is likely to be modest. ${ }^{35}$ The SSP experimental results do not provide much guidance on the likely magnitude of entry effects for other programs without a one-year "waiting period" requirement.

\section{Non-Experimental Evidence on the EITC and Enhanced Disregards}

While systematic evaluations of financial incentive programs are still ongoing, it is probably safe to say that financial incentive programs are on the rise in the U.S., regardless of the ultimate conclusions of these evaluations. At the federal level, the Earned Income Tax Credit (EITC) program, which provides earnings subsidies for low-income families with children, has been substantially expanded in the past 5 years. At the state level, many states have moved rapidly in the wake of the TANF legislation to introduce financial incentives into their welfare systems -- most often via proportional earnings disregards. In this section we briefly review some evidence on the effects of these program innovations.

\section{A. The EITC}

The Earned Income Tax Credit (EITC) is a financial incentive program that has been in operation nationally since 1975 . Prior to 1994 , the subsidy was relatively small. ${ }^{36}$ With recent expansions, however, the program is now larger (in terms of total Federal dollars spent) than

\footnotetext{
${ }^{35}$ Card, Robins and Lin (1997) note that information about SSP eligibility did not seem to lead to any increase in welfare duration for people who would have stayed on income assistance for 3 months or less. Based on this finding for short-term welfare participants, they argue that it is unlikely that many people who never entered welfare would be enticed to enter and remain on for a full year to gain SSP.

${ }^{36}$ See Meyer and Rosenbaum (1998) and Liebman (1998) for a history of the EITC.
} 
any other income supplement program, including the TANF block grant, the Food Stamp Program, or the Supplemental Security Income Program (SSI). Between 1990 and 1997, the real EITC maximum subsidy rose 212 percent for a family with two children.

The EITC provides a phased earnings credit (or an earnings subsidy). In 1997, for a single parent with two children the subsidy was 40 percent of annual earnings, up to a maximum of $\$ 3,656$, which is reached when earnings exceed $\$ 9,140$. For families with earnings between $\$ 9,140$ and $\$ 11,930$ the credit is constant. Thereafter, it phases out at a rate of 21.06 percent, leading to zero payments after earnings exceed $\$ 29,290$. Because the EITC is not counted as income in the computation of welfare grants in most states, the EITC provides a work incentive for welfare recipients, even in states with a 100 percent implicit tax rate on earnings. Budget constraints for the combined EITC-TANF program are presented in Figures $7 \mathrm{a}$ and $7 \mathrm{~b}$ for a single parent with two children who lives in a state with a $\$ 400$ basic welfare grant and a fixed ( $\$ 90$ per month) earnings disregard. Figure 7a shows the budget constraint for a minimum wage earner while Figure $7 \mathrm{~b}$ shows the constraint for a single parent who earns $\$ 8.00$ per hour (about the national average for single mothers who receive AFDC). Inspection of the graphs show that the EITC introduces fairly generous financial incentives for work.

Despite its size and importance, there has been no formal experimental evaluation of the financial incentives provided by the EITC. However, there have been several nonexperimental evaluations of the program (for example, Eissa and Liebman, 1996 and Hoffman and Seidman, 1990). The basic strategy of Eissa and Liebman (1996) is to compare the trends in employment and hours outcomes for single mothers with children to those of other women. 
An update of a key graph in their paper is presented in Figure 8. Here, we plot average annual weeks of work for single mothers, single women with no children, and married women without children, derived from March Current Population Survey data for 1979-1997. (Married women with children are also eligible for the EITC. Recent work by Eissa and Hoynes (1998) suggests that the program reduces their labor supply slightly). The graph shows a rather remarkable upsurge in work activity of single mothers since 1993 relative to either comparison group of childless women. ${ }^{37}$ The timing of this upsurge occurs just as major EITC expansions were enacted. Between 1993 and 1997, the real value of the maximum EITC credit rose 118 percent (39 percent) for a single mother with two children (one child). Whether the entire rise in labor supply is attributable to the EITC is debatable (see below). Nevertheless, it seems clear that single mothers' relative labor supply trends have tracked the rise of the EITC rather closely, suggesting that the EITC's financial incentives may have raised work effort among single women. ${ }^{38}$

It is worth noting that the simple comparisons in Figure 8 include the labor supply of all single mothers -- not just welfare recipients or low-earning mothers. In principle, the EITC lowers the work effort of single mothers whose earnings fall in the phase-out range, because for these women it lowers their post-tax wage and raises their incomes. However, this effect

\footnotetext{
${ }^{37}$ We constructed the changes in average weeks from a base period of 1990-93 to an end period of 1997 for the three groups. Single mothers' weeks rose by 4.39 weeks (standard error 0.35 ); married women without children's weeks rose 0.47 weeks (standard error 0.27 ) and single women without children's weeks fell 1.05 weeks (standard error 0.29). Comparing single mothers to married women without children, the relative rise is 3.9 weeks (standard error 0.4). Comparing single mothers to single women without children the relative rise is 5.4 weeks (standard error 0.4 ).

${ }^{38}$ Meyer and Rosenbaum (1998) indicate that the EITC increases explain 33 percent of the rise in single mother's labor force participation between 1992 and 1996. The minimum wage also rose between 1990 and 1997 , from $\$ 4.34$ to $\$ 5.15$ (\$1997). This would also increase the returns to work among the least skilled.
} 
does not seem to have dominated the positive effects for other groups.

\section{B. Enhanced Earnings Disregards}

From 1967 until 1981, the federal AFDC program provided modest financial incentives for welfare recipients to work, in the form of a 33 percent earnings disregard. Reforms introduced in 1982 eliminated this feature and replaced it with a flat disregard that substantially reduced the economic incentives for work among welfare recipients. Beginning in the early 1990s, some states were granted waivers to the AFDC program rules; a subset of these states introduced enhanced disregards, such as the Florida FTP program described in Table 1. Following the elimination of the AFDC system in 1996 and its replacement by the decentralized TANF program, most states (41 at latest count) have introduced some form of a proportional earnings disregard (see Gallagher, et al, 1998, or U.S. GAO, 1998).

While there has been a great deal of attention paid to the effects of welfare reform on the welfare caseloads in many states, less attention has been paid to the effects of changing financial incentives on the probability that welfare recipients work. Table 8 presents some simple data on welfare participation rates, work activity, and poverty rates for all single mothers, single mothers who received welfare at some point over the year, and single mothers who received welfare in every month of the year. ${ }^{39}$ The first column of the table shows that although welfare participation rates fluctuated in a narrow band over the 1980s, rates have plummeted since 1993. At the same time, the fraction of single mothers who worked (at any

\footnotetext{
${ }^{39}$ Starting in 1989 , the CPS includes questions on how many months welfare was received over the previous year.
} 
time in the year) has risen sharply (mirroring the trend in average weeks of work in Figure 8). ${ }^{40}$ The fraction of single mothers whose families are poor has remained more stable.

Among single mothers who receive welfare, and among full-year recipients in particular, labor supply has increased dramatically since 1993. In fact, the 14 percentage point rise in work by AFDC recipients from 1993 to 1997 accounts for close to one-half of the rise in work by all single mothers. In the early 1990 s, about 20 percent of full-year welfare recipients reported any work during the year. On average, they worked only 5 weeks per year. By 1997, the fraction of full-year welfare recipients reporting work had almost doubled, and the average weeks of work had more than doubled. These rises are especially notable in view of the rapid decline in welfare participation, which might have been expected to shift the pool of remaining welfare participants toward a more disadvantaged and less work-ready population. Even with this potential selection effect, however, work effort among welfare recipients has risen. ${ }^{41}$

While part of the rise in work effort among welfare recipients may be due to the EITC, some is also potentially attributable to the adoption of enhanced disregards. One simple way to measure the latter contribution is to compare trends in labor supply in two groups of states --

\footnotetext{
${ }^{40}$ It is interesting to note that the fraction of AFDC recipients who worked, and mean weeks of work, both fell between 1982 and 1983, and were much lower in the mid-1980s than in the 1979-81 period. This probably reflects both the introduction of 100 percent tax rates on earnings in 1982 and other changes in eligibility rules that made it more difficult for working parents to remain on AFDC. It is worth noting that prior to 1983 there were errors in the CPS count of single mothers (London, 1998). Alternative tabulations to account for these errors seem to provide similar poverty rates (private communication with Rebecca London).

${ }^{4 \mathrm{i}}$ For more detailed information about work trends among AFDC recipients in the 1990s, see Polivka (1998). Note that there is evidence that the CPS undercount of AFDC recipients has grown worse in the mid-1990s. It is not clear how this will affect the employment and poverty counts for AFDC recipients shown in Table 8 . It should not affect the lone mother data.
} 
those that were early adopters of enhanced disregards, adopting them before 1996, and those that were late adopters (or have not yet adopted them). We used a tabulation of disregard features in Gallagher et al (1998, Tables 14 and 15) to identify 11 states that adopted proportional disregards prior to $1996 .^{42}$ We then constructed average weeks of work for single mothers and for AFDC recipients in the "early adopter" states and other states over the period from 1988 to 1997 . The results, plotted in Figure 9, show that weeks of work in the two groups of states were very similar from 1988 to 1994 . By 1997 in early adopter states, weeks of work are 6 weeks higher for welfare recipients and 1.3 weeks points higher for all lone mothers. ${ }^{43}$ Of course some of the early adopter states may have also adopted other program features in their welfare system, such as more intensive case management. Thus, one should not attribute all of the increase in work effort to financial incentives. Nevertheless, the simple cross-state patterns are suggestive, and fairly consistent with the experimental results in the previous section. In particular, one might conclude that enhanced disregards raised weeks of work by about 5 percent in the early adopter states. ${ }^{44}$ At a minimum the simple comparisons in Figure 9 point out the potential value of a more detailed investigation of the effects of

\footnotetext{
${ }^{42}$ These are Connecticut, Florida, Illinois, Iowa, Massachusetts, Michigan, Montana, Ohio, Vermont, Utah, and Virginia. The proportional earnings disregards in these states average about 50 percent.

${ }^{43}$ Since about 30 percent of all single mothers receive AFDC, the rise in work among AFDC recipients only should have produced a 1.7 week rise in weeks of work among all single mothers. This assumes, however, that the AFDC population is remaining constant. In the presence of financial incentives, some "windfall beneficiaries" might begin to receive AFDC benefits, which would cause changes in weeks of work among AFDC women to be somewhat overstated over time. The AFDC caseload drops equally in both groups of states over this time period, however.

${ }^{44}$ An exact comparison with the experiments is difficult because the March CPS data pertain to average weeks of work during the last year. We also constructed similar comparisons of relative trends in employment rates. These show similar, but somewhat smaller, differences than the weeks of work data between the early adopter and late adopter states.
} 
enhanced earnings disregards in some of the early adopter states.

\section{Conclusions and Policy Implications}

The available evidence on financial incentive programs suggests that these programs can increase work and raise income (reduce poverty). These effects appear to be larger in the more generous programs. Such results indicate that financial incentive programs also cost more than the alternative welfare system, at least initially. Because these programs transfer more support to working low-income families, this increase in costs may be acceptable if the increases in work and income are highly valued.

A key determinant of the impact of financial incentive programs is the relative fraction of people who are incentivized to work (or work more) by the program, versus the number of windfall beneficiaries who receive income supplements but who would be working even in the absence of the program. If one places a high priority on the goal of poverty alleviation, the presence of these windfall beneficiaries may not be viewed as a problem. But if one is concerned about cost issues, windfall beneficiaries substantially add to the cost of the program. Current programs adopt a number of provisions to limit the presence of windfall beneficiaries, including eligibility restrictions that target benefits to long-term welfare recipients, and hours restrictions that limit benefits to full-time workers. Comparisons based on the SSP experiment indicate that the relative fraction of windfall recipients varies by education level and past work history, suggesting that other targeting restrictions might be useful in limiting the fraction of windfall beneficiaries. Of course, the more narrowly targeted the program, and the more limited its eligibility rules, the less it will accomplish in terms of poverty alleviation. 
Windfall participation can also be affected by the "stigma" associated with the program, although none of the current experiments allow a direct test of this hypothesis. Different financial incentive programs present different degrees of stigma for windfall beneficiaries. At one extreme, the EITC is widely available to all low income parents and has no stigma (it is received solely by filing one's personal income tax forms). SSP and New Hope operate outside traditional welfare programs and probably have less stigma than similar incentive programs that operate as part of the traditional welfare system. The more that welfare programs impose behavioral requirements (beyond work), the lower the participation among those not previously on welfare, particularly if their benefit levels would be small. In this regard, the "get tough" attitude that has prevailed in the U.S. over the past decade may be particularly important in reducing windfall participation.

Entry effects may increase the number of windfall beneficiaries over time. Some of the current experimental programs, which are available only to welfare participants, may understate the size of the windfall beneficiary population that would ultimately emerge if financial incentives were more widely available. Nevertheless, an experimental evaluation of entry effects for the SSP program suggest that eligibility restrictions (such as a requirement to have received welfare benefits for at least a year) may effectively reduce potential entry effects.

The combination of financial incentives with various types of employment services appears to result in even larger increases in employment and income, and may lower the cost of the financial incentive programs. There is not enough evidence to say anything conclusive about whether mandatory employment programs, with stronger "sticks," work better than 
voluntary services. The existing evidence is at least suggestive that the combination of the financial incentive "carrots" with mandatory job search assistance "sticks" can produce larger employment and income increases than either program by itself.

Financial incentive programs are on the rise, and are a key part of most state's newlyenacted TANF-funded programs. At the Federal level, the expansion in the EITC (and the minimum wage) also increases the available financial incentives for less skilled persons to enter the workforce. Both the expansion of the EITC and the adoption of enhanced earnings disregards by state programs appear to have had significant effects on the work effort of single parents.

More information on the impact of financial incentive programs will become available in the near future, as evaluations from more demonstration programs become available, and as researchers investigate the effect of state earnings disregards over time. Among the key issues that deserve further research attention are: the interaction of financial incentive programs with other welfare reform measures (particularly more mandatory employment requirements); the ways in which financial incentive programs are successful or unsuccessful in avoiding a growing share of windfall beneficiaries over time; the long-term impact of financial incentive programs on employment, income, and public costs; and the willingness of government to fund these programs as both their advantages and their disadvantages become more apparent in the years ahead. 


\section{References}

Ashenfelter, Orley, "Determining Participation in Income-Tested Social Programs." Journal of the American Statistical Association, 78, September 1983, pp. 517-25.

Blank, Rebecca M. and Patricia Ruggles, "When Do Women Use AFDC and Food Stamps? The Dynamics of Eligibility vs. Participation." Journal of Human Resources, 31 , Winter 1996, pp. 57-89.

Bloom, Dan, Mary Farrell, James J. Kemple, and Nandita Verma, The Family Transition Program: Implementation and Interim Impacts of Florida's Initial Time-Limited Welfare Program, New York: Manpower Demonstration Research Corporation, April 1998.

Card, David and Philip K. Robins, "Do Financial Incentives Encourage Welfare Recipients to Work? Initial Findings from the Self-Sufficiency Project." Research in Labor Economics, Vol 17, Solomon Polachek, ed. Greenwich, CN: JAI Press. 1998.

Card, David, Philip K. Robins, and Winston Lin, How Important are "Entry Effects" in Financial Incentive Programs for Welfare Recipients? Experimental Evidence from the Self-Sufficiency Project. Ottawa, Ontario: Social Research and Demonstration Corporation, August 1997.

Eissa, Nada and Jeffrey Liebman, "Labor Supply Response to the Earned Income Tax Credit," Quarterly Journal of Economics, 112 (2), May 1996, pp. 605-637.

Eissa, Nada and Hilary Hoynes, "The Earned Income Tax Credit and the Labor Supply of Married Couples." Unpublished paper, June 1998.

Friedlander, Daniel, David H. Greenberg, and Philip K. Robins, "Evaluating Government Training programs for the Economically Disadvantaged, Journal of Economic Literature, 35 (4), December 1997, pp. 1809-55.

Gallagher, L. Jerome, Megan Gallagher, Kevin Perese, Susan Schreiber, and Keith Watson, "One Year After Federal Welfare Reform: A Description of State Temporary Assistance for Needy Families (TANF) Decisions as of October 1997." Occasional Paper Number 6, Assessing the New Federalism Project. Washington, D.C.: The Urban Institute, June 1998.

Garfinkel, Irwin, Philip K. Robins, Pat Wong, and Daniel R. Meyer, "The Wisconsin Child Support Assurance System: Estimated Effects on Poverty, Labor Supply, Caseloads, and Costs." Journal of Human Resources, 25 (1), Winter 1990, pp. 1-31. 
Gueron, Judith M. and Edward Pauly, From Welfare to Work. New York: Russell Sage Foundation, 1991.

Hamilton, William L., Nancy R. Burstein, August J. Baker, Alison Earle, Stefanie Gluckman, Laura Peck, and Alan White, The New York State Child Assistance Program: Five year Impacts, Costs, and Benefits. Cambridge, MA: Abt Associates, October 1996.

Hoffman, Saul D. and Laurence Seidman, The Earned Income Tax Credit: Antipoverty Effectiveness and Labor Market Effects. Kalamazoo, MI: The Upjohn Institute for Employment Research, 1990.

Keeley, Michael C., Philip K. Robins, Robert G. Spiegelman, and Richard W. West, "The Labor Supply Effects and Costs of Alternative Negative Income Tax Programs," Journal of Human Resources 13 (1), Winter 1978, pp. 3-36.

Liebman, Jeffrey B., "Is the Earned Income Tax Credit a Solution to Welfare Dependency, Earnings Inequality, and Poverty? Tradeoffs in the Design of Transfer Programs," Unpublished Manuscript, September 1996.

Liebman, Jeffrey B., The Impact of the Earned Income Tax Credit on Incentives and Income Distribution." Tax Policy and the Economy, 12, 1998, pp. 83-119.

Lin, Winston, Philip K. Robins, David Card, Kristen Harknett, Susanna Lui-Gurr, and others, When Financial Incentives Encourage Work: Complete 18-Month Findings from the Self-Sufficiency Project, Ottawa, Ontario, Canada, Social Research and Demonstration Corporation, September 1998.

London, Rebecca A., "Trends in Single Mothers Living Arrangements from 1970 to 1995 : Correcting the Current Population Survey." Demography, 35, February 1998, pp. 125-31.

Meyer, Bruce D. and Dan T. Rosenbaum, "Welfare, the Earned Income Tax Credit, and the Employment of Single Mothers.” Unpublished paper, October 1998.

Miller, Cynthia, Virginia Knox, Patricia Auspos, Jo Anna Hunter-Manns, and Alan Orenstein, Making Welfare Work and Work Pay: Implementation and 18-Month Impacts of the Minnesota Family Investment Program. New York: Manpower Demonstration Research Corporation, October 1997.

Moffitt, Robert A., “An Economic Model of Welfare Stigma.” American Economic Review, 73(5), December 1983, pp. 1023-35.

Moffitt, Robert A., “The Effect of Employment and Training Programs on Entry and Exit 
from the Welfare Caseload." Journal of Policy Analysis and Management, 15 (1), Winter 1996, pp. 32-50.

Quets, Gail, Philip K. Robins, Elsie Pan, Charles Michalopoulos, and David Card, Adding Employment Services to the Self-Sufficiency Project's Financial Incentives:

Implementation and 18-Month Results of the SSP Plus Study. Ottawa, Ontario: Social Research and Demonstration Corporation, forthcoming 1999.

Polivka, Anne, "Note on the Possible Effects of Welfare Reform on Labor Market Activities: What Can Be Gleaned from the March CPS?" Bureau of Labor Statistics: Unpublished manuscript. 1998.

Robins, Philip K., “A Comparison of the Labor Supply Findings from the Four Negative Income Tax Experiments." Journal of Human Resources, 20(4), Fall 1985, pp. 56782 .

Shore-Sheppard, Lara D., "Stemming the Tide? The Effects of Expanding Medicaid Eligibility on Health Insurance Coverage." Unpublished manuscript, November 1997.

U.S. General Accounting Office, Welfare Reform: States are Restructuring Programs to Reduce Welfare Dependence, GAO/HEHS-98-109, Washington, D.C., U.S. Government Printing Office, June 1998. 
Table 1

Programs Providing Financial Incentives

Panel A - Within the Existing Welfare System

( $\mathrm{E}=$ Experimentals; $\mathrm{C}=$ Controls)

\begin{tabular}{|c|c|c|c|c|}
\hline $\begin{array}{l}\text { Program } \\
\text { Year begun } \\
\text { Site(s) }\end{array}$ & Eligibility & $\begin{array}{c}\text { Evaluation } \\
\text { Sample Sizes }\end{array}$ & Financial Incentives Tested & Other Features \\
\hline $\begin{array}{l}\text { Family Investment Program (MFIP) } \\
1994 \\
\text { Minnesota ( } 3 \text { urban and } 4 \text { rural counties) }\end{array}$ & Welfare recipients & $\begin{array}{c}5,275 \mathrm{E} 1 \mathrm{~s} \\
\text { (incentives+job } \\
\text { services) } \\
1,933 \mathrm{E} 2 \mathrm{~s} \\
\text { (incentives only) } \\
\text { 7,431 Cs }\end{array}$ & $\begin{array}{c}\text { Increased basic grant (for workers) } \\
\text { (20\% above standard grant) } \\
\text { Enhanced earnings disregard } \\
(38 \%) \\
\text { Elimination of } 100 \text { hour work rule } \\
\text { (2-parent cases) } \\
\text { Reimbursed work-related expenses } \\
\text { Increased asset limit }\end{array}$ & $\begin{array}{l}\text { MFIP benefit cannot exceed the } \\
\text { standard AFDC grant } \\
\text { Mandatory case management for a } \\
\text { subset of the E1s who work less than } \\
30 \text { hours per week } \\
\text { Child care assistance } \\
\text { Food stamp cash out }\end{array}$ \\
\hline $\begin{array}{l}\text { Welfare Restructuring Project (WRP) } \\
1994 \\
\text { Vermont (12 Welfare Districts, } 6 \text { being } \\
\text { evaluated) }\end{array}$ & Welfare recipients & $\begin{array}{l}6,600 \mathrm{E} 1 \mathrm{~s} \\
\text { (incentives+ } \\
\text { time-trigger) } \\
\text { 2,200 E2s } \\
\text { (incentives only) } \\
\text { 2,200 Cs }\end{array}$ & $\begin{array}{c}\text { Enhanced earnings disregard } \\
\text { (\$150 plus } 25 \%) \\
\text { Elimination of } 100 \text { hour work rule } \\
\text { (2-parent cases) } \\
\text { Increased asset limit }\end{array}$ & $\begin{array}{c}\text { "Work triggered" time limit } \\
\text { (1 parent after } 30 \text { months, } 2 \text { parent } \\
\text { after } 15 \text { months) } \\
\text { Extended transitional Medicaid } \\
\text { (3 years) } \\
\text { Extended transitional child care } \\
\text { (available if income<state median) } \\
\text { Temporary job placement } \\
\text { Support services }\end{array}$ \\
\hline $\begin{array}{l}\text { Family Transition Program (FTP) } \\
1994 \\
\text { Florida ( } 2 \text { counties, } 1 \text { being evaluated) }\end{array}$ & Welfare recipients & $\begin{array}{l}1,405 \mathrm{Es} \\
1,410 \mathrm{Cs}\end{array}$ & $\begin{array}{c}\text { Enhanced earnings disregard } \\
(\$ 200 \text { plus } 50 \%) \\
\text { Increased asset limit }\end{array}$ & $\begin{array}{c}\text { Case management } \\
\text { (1 parent after } 2 \text { years, } 2 \text { parent after } 6 \\
\text { months } \\
\text { Extended transitional child care }(2 \\
\text { years) } \\
\text { Time limit ( } 2 \text { or } 3 \text { years })\end{array}$ \\
\hline $\begin{array}{l}\text { Jobs First (JF) } \\
1996 \\
\text { Connecticut (Manchester and New Haven) }\end{array}$ & Welfare recipients & $\begin{array}{l}2,756 \mathrm{Es} \\
2,752 \mathrm{Cs}\end{array}$ & $\begin{array}{c}\text { Full earnings disregard (for earnings below } \\
\text { poverty level) } \\
\text { Increased asset limit }\end{array}$ & $\begin{array}{c}\text { Family caps } \\
\text { Job-search assistance } \\
\text { Extended transitional health benefits (2 } \\
\text { years) } \\
\text { Time limit (21 months, with possible } \\
\text { 6-month extension) }\end{array}$ \\
\hline
\end{tabular}


Table 1 (concl.)

Programs Providing Financial Incentives

Panel B - Outside the Existing Welfare System

( $\mathrm{E}=$ Experimentals; $\mathrm{C}=$ Controls $)$

\begin{tabular}{|c|c|c|c|c|}
\hline $\begin{array}{l}\text { Program } \\
\text { Year begun } \\
\text { Site(s) }\end{array}$ & Eligibility & $\begin{array}{l}\text { Evaluation } \\
\text { Sample } \\
\text { Sizes }\end{array}$ & Financial Incentives Tested & Other Features \\
\hline $\begin{array}{l}\text { Self-Sufficiency Project (SSP) } \\
1992 \\
\text { British Columbia } \\
\text { New Brunswick }\end{array}$ & $\begin{array}{l}\text { Single parent families on } \\
\text { welfare for at least one year }\end{array}$ & $\begin{array}{l}2,880 \mathrm{Es} \\
2,859 \mathrm{Cs}\end{array}$ & $\begin{array}{c}\text { Earnings supplement } \\
{[.5 \text { (target earnings - actual earnings)] }} \\
\text { Target earnings }=\$ 30,000 \text { in New Brunswick, } \\
\$ 37,000 \text { in British Columbia } \\
\text { Minimum hours requirement (30/week) }\end{array}$ & $\begin{array}{c}\text { Benefits do not vary with family size } \\
\text { Wage income taxed at } 50 \% \\
\text { Nonwage income not taxed } \\
\text { Job Search assistance for a } \\
\text { supplemental sample } \\
\text { in New Brunswick } \\
\text { Time limit (3 years) }\end{array}$ \\
\hline $\begin{array}{l}\text { New Hope (NH) } \\
1994 \\
\text { Milwaukee }\end{array}$ & $\begin{array}{c}\text { Any household with income } \\
\text { less than } 150 \text { percent of } \\
\text { poverty level }\end{array}$ & $\begin{array}{l}678 \mathrm{Es} \\
679 \mathrm{Cs}\end{array}$ & $\begin{array}{l}\text { Earnings supplement } \\
\text { (mimics the EITC formula, } 25 \% \text { phase-in, } 20 \% \\
\text { phase-out, maximum supplement at earnings of } \\
\$ 8,500 \text { is } \$ 2,125 \text {, supplement fully phased out } \\
\text { at earnings of } \$ 20,000 \text { ) } \\
\text { Minimum hours requirement ( } 30 / \text { week) }\end{array}$ & $\begin{array}{l}\text { Adjustment for family size } \\
\text { Job-search assistance } \\
\text { Temporary job placement } \\
\text { Child care and health care assistance } \\
\text { Time limit ( } 3 \text { years) }\end{array}$ \\
\hline $\begin{array}{l}\text { Child Assistance Program (CAP) } \\
1989 \\
\text { 3 New York counties }\end{array}$ & $\begin{array}{l}\text { Single parent welfare } \\
\text { recipients with a child support } \\
\text { order }\end{array}$ & $\begin{array}{l}2,144 \mathrm{Es} \\
2,143 \mathrm{Cs}\end{array}$ & $\begin{array}{l}\text { Enhanced earnings disregards } \\
\text { Lower benefit reduction rates } \\
(10 \% \text { and } 67 \%) \\
\text { Increased asset limit }\end{array}$ & $\begin{array}{l}\text { 1/3 lower basic benefit level } \\
\text { Food stamps cash out } \\
\text { Case management }\end{array}$ \\
\hline
\end{tabular}


Table 2

Impacts of Financial

Incentives on Employment

and Earnings

of Single Parent Welfare

Recipients

\begin{tabular}{|c|c|c|c|c|}
\hline & $\mathrm{SSP}^{\mathrm{a}}$ & $\mathrm{CAP}^{\mathrm{D}}$ & $\mathrm{MFIP}^{\mathrm{C}}$ & FTP $^{d}$ \\
\hline \multicolumn{5}{|l|}{ Employment (\%) } \\
\hline Treatment group mean & 40.8 & 24.2 & 42.0 & 48.5 \\
\hline Control group mean & 29.0 & 21.4 & 36.1 & 42.2 \\
\hline Impact & $11.8^{\star \star *}$ & $2.8^{* * *}$ & $5.9^{* * *}$ & $6.3^{* * *}$ \\
\hline \multicolumn{5}{|c|}{ Full-time employment (\%) } \\
\hline Treatment group mean & 28.9 & n.a. & 26.9 & 63.9 \\
\hline Control group mean & 14.4 & n.a. & 29.9 & 56.4 \\
\hline Impact & $14.5^{* \star *}$ & n.a. & -3.0 & $7.5^{\star}$ \\
\hline \multicolumn{5}{|l|}{ Annual earnings ${ }^{e}$} \\
\hline Treatment group mean & $\$ 3,378$ & $\$ 3,051$ & $\$ 3,129$ & $\$ 4,044$ \\
\hline Control group mean & $\$ 2,160$ & $\$ 2,410$ & $\$ 3,142$ & $\$ 3,363$ \\
\hline Impact & $\$ 1,219^{* * *}$ & $\$ 641$ ** & $-\$ 13$ & $\$ 682 * * *$ \\
\hline
\end{tabular}

CAP

SSP

SSP

FTP, SSP

FTP, MFIF

SSP 
Table 3

Impacts of Financial Incentives

CPI on Receipt and Amount of Cash

Assistance

of Long-Term Single Parent Welfare

Recipients

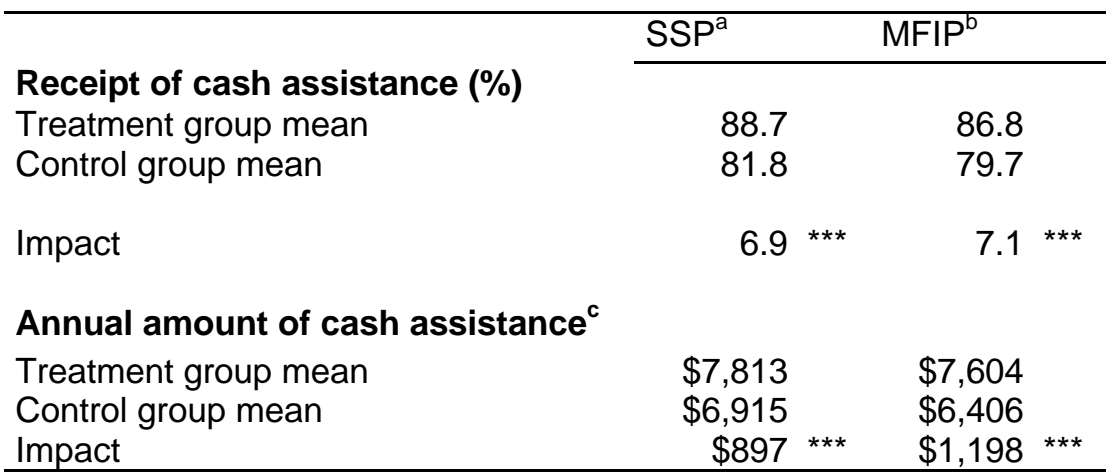

CAP

SSP

1994

FTP, SSP

1995

FTP, MFIP,

SSP

1997

Annual amount of cash assistance

Control group mean 


\section{Table 4 \\ Impacts of Financial \\ Incentives on Full- \\ Time Employment \\ and Extent of Windfall \\ by Subgroup \\ of Long-Term Single \\ Parent Welfare \\ Recipients in SSP ${ }^{\mathrm{a}}$}

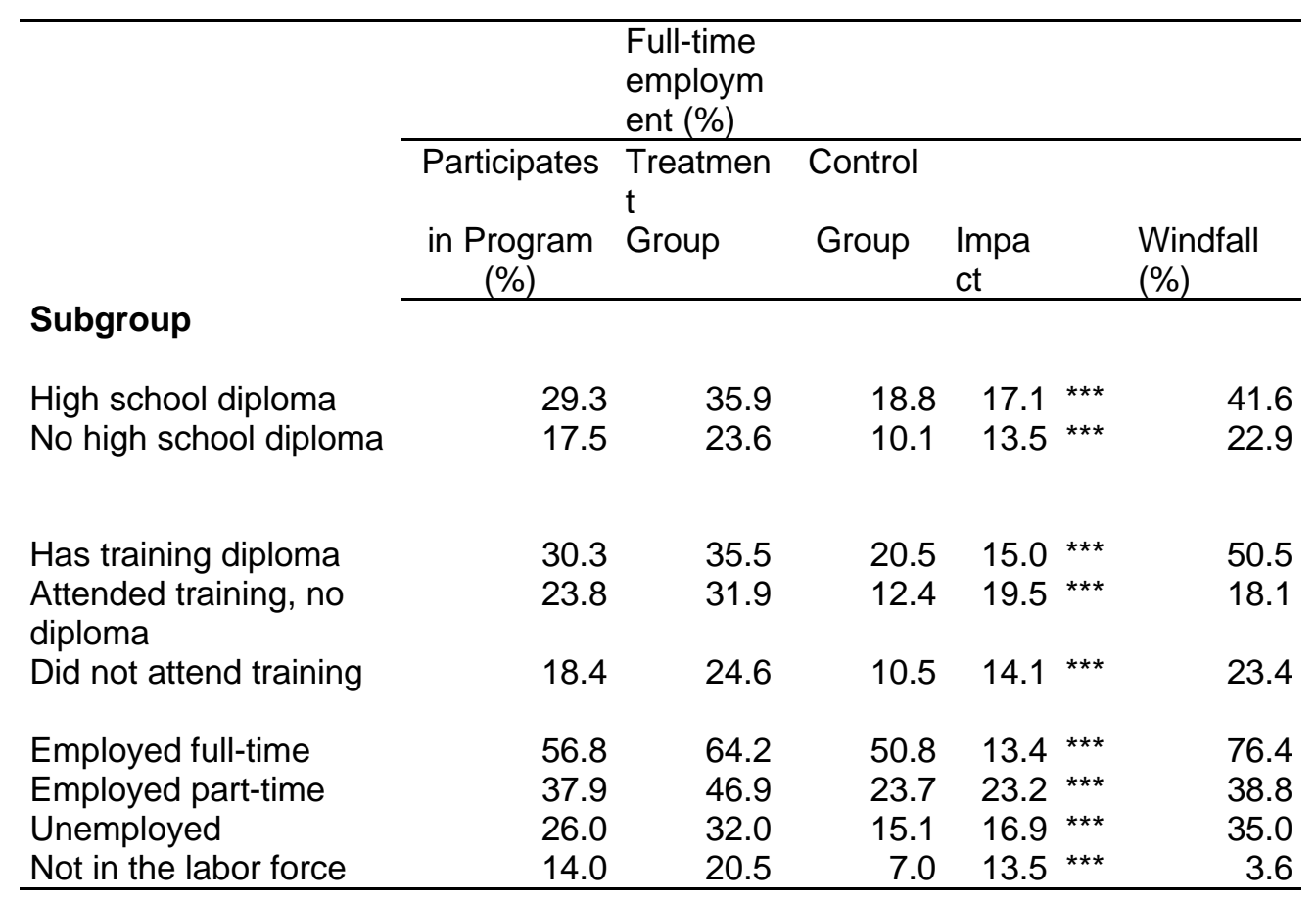

CAP

SSP

SSP

FTP, SSP

FTP, MFIP,

SSP

CF

Full-time 
Table 5

Impacts of Financial Incentives on

CPI

Income and Poverty

of Long-Term Single Parent Welfare

Recipients

\begin{tabular}{lrr}
\hline & $\mathrm{SSP}^{\mathrm{a}}$ & $\mathrm{MFIP}^{\mathrm{D}}$ \\
\cline { 2 - 3 } Family Annual Income $^{\mathrm{c}}$ & & \\
Treatment group mean $_{\text {Control group mean }}$ & $\$ 14,263$ & $\$ 10,746$ \\
& $\$ 12,343$ & $\$ 9,634$ \\
Impact & $\$ 1,920^{* * *}$ & $\$ 1,112^{* * *}$ \\
& & \\
Poverty Rate (\%) & & \\
Treatment group mean & 21.1 & 75.7 \\
Control group mean & $31.9^{* * *}$ & $85.2^{* * *}$ \\
Impact & $-10.8^{* *}$ & $-9.5^{* *}$ \\
\hline
\end{tabular}

CAP

1992

SSP 1993

SSP $\quad 1994$

FTP, SSP

1995

FTP, MFIP,

1996

SSP

1997

Poverty Rate (\%)

Treatment group mean

Impact 
Table 6

Impacts of Financial

Incentives Plus Services on

Employment and Earnings

of Long-Term Single Parent

Welfare Recipients

Employment (\%)

Treatment group mean

Control group mean

Impact

Full-time employment (\%)

Treatment group mean

Control group mean

Impact

Annual earnings ${ }^{c}$

Treatment group mean

Control group mean

Impact

\begin{tabular}{lllll}
\hline SSP $^{\mathrm{a}}$ & & & MFIP $^{\mathrm{b}}$ & \\
\hline Financial & Financial & $\begin{array}{l}\text { Incremen } \\
\text { tal }\end{array}$ & Financial & Financial \\
Incentives & Incentives & $\begin{array}{l}\text { Impact of } \\
\text { Only }\end{array}$ & Incentives & Incentives \\
& + & Services & Only & + \\
& Services & & & Services \\
\hline
\end{tabular}

40.9

32.3

$8.6^{* * *}$

29.6

16.2

$13.4^{* *}$

33.3

16.2

$17.1^{\star \star \star}$

$-$

$-$

3.7

$-$

6.9 *

42.0

36.1

51.7

36.1

$5.9^{* * *}$

$15.6^{* \star *}$

$\$ 2,745$
$\$ 2,227$
$\$ 518$

$\$ 3,340$

$\$ 2,227$

$\$ 1,113$
26.9

29.9

$-3.0$

39.4

29.9

9.5

\begin{tabular}{cr}
- & $\$ 3,129$ \\
- & $\$ 3,142$ \\
$\$ 595 *$ & $-\$ 13$ \\
\hline
\end{tabular}

$\$ 4,142$

$\$ 3,142$

$\$ 999$ 
Table 7

Impacts of Financial Incentives Plus

Services on Receipt and Amount of

Cash Assistance

of Long-Term Single Parent Welfare

Recipients

Receipt of cash assistance (\%)

Treatment group mean

Control group mean

\begin{tabular}{lllll} 
SSP $^{\mathrm{a}}$ & & & MFIP $^{\mathrm{b}}$ & \\
\hline Financial & Financial & Incremen & Financial & Financic \\
& & tal & & \\
Incentives & Incentives & Impact of & Incentives & Incentiv \\
Only & + & Services & Only & + \\
& Services & & & Services \\
\hline
\end{tabular}

Impact

87.7

79.1

84.7

79.1

$8.6^{* * *}$

$5.6^{* *}$

$\$ 6,455$

$\$ 5,471$

$\$ 984^{* *}$
$\$ 6,474$

$\$ 5,471$

$\$ 1,003$

$\$ 19$

$\$ 7,604$

$\$ 6,406$

$\$ 1,198$

$\$ 6,9$

$\$ 19$

Impact

Annual amount of cas 


\begin{tabular}{|c|c|c|c|c|c|c|c|c|c|}
\hline $\begin{array}{l}\text { Table } 8 \\
\text { Progra } \\
\text { m } \\
\text { Particip } \\
\text { ation, } \\
\text { Work } \\
\text { Activity } \\
\text {, and } \\
\text { Poverty } \\
\text { Rates } \\
\text { of Lone } \\
\text { Mother } \\
\text { s, 1979- } \\
97\end{array}$ & & & & & & & & & \\
\hline & $\begin{array}{l}\text { All Lone } \\
\text { Mothers }\end{array}$ & & & $\begin{array}{l}\text { FDC } \\
\text { ecipie } \\
\text { s }\end{array}$ & & & $\begin{array}{l}\text { Gull- } \\
\text { Year } \\
\text { Recipie } \\
\text { its }\end{array}$ & & \\
\hline & $\begin{array}{l}\text { Prob. } \\
\text { AFDC }\end{array}$ & $\begin{array}{l}\text { Prob. } \\
\text { Work }\end{array}$ & $\begin{array}{r}\text { Poverty } \\
\text { Rate } \\
\end{array}$ & $\begin{array}{l}\text { Prob. } \\
\text { Work }\end{array}$ & $\begin{array}{r}\text { Mean } \\
\text { Weeks }\end{array}$ & $\begin{array}{r}\text { Poverty } \\
\text { Rate } \\
\end{array}$ & $\begin{array}{l}\text { Prob. } \\
\text { Work }\end{array}$ & $\begin{array}{r}\text { Mean } \\
\text { Weeks }\end{array}$ & $\begin{array}{r}\text { Poverty } \\
\text { Rate } \\
\end{array}$ \\
\hline 1979 & 31.0 & 68.8 & 42.5 & 40.2 & 11.6 & 75.6 & -- & -- & -- \\
\hline 1980 & 30.6 & 67.4 & 46.3 & 35.0 & 9.6 & 83.6 & -- & -- & -- \\
\hline 1981 & 31.7 & 64.9 & 50.2 & 33.9 & 9.5 & 85.5 & -- & -- & -- \\
\hline 1982 & 31.2 & 61.9 & 54.1 & 29.4 & 7.2 & 90.8 & -- & -- & -- \\
\hline 1983 & 30.8 & 62.2 & 53.7 & 26.7 & 6.1 & 92.2 & -- & -- & -- \\
\hline 1984 & 30.6 & 64.5 & 52.6 & 26.8 & 6.4 & 91.5 & -- & -- & -- \\
\hline 1985 & 30.3 & 65.5 & 52.5 & 30.5 & 7.1 & 91.6 & -- & -- & -- \\
\hline 1986 & 31.1 & 65.5 & 52.6 & 29.9 & 7.6 & 90.3 & -- & -- & -- \\
\hline 1987 & 30.6 & 65.1 & 53.0 & 32.5 & 8.1 & 90.4 & -- & -- & -- \\
\hline 1988 & 29.2 & 66.9 & 50.8 & 34.1 & 8.6 & 90.5 & 21.2 & 5.2 & 92.5 \\
\hline 1989 & 26.8 & 68.2 & 48.4 & 32.0 & 8.2 & 88.6 & 16.2 & 3.5 & 92.7 \\
\hline 1990 & 29.3 & 67.8 & 51.2 & 35.3 & 8.8 & 89.3 & 20.3 & 4.6 & 91.9 \\
\hline 1991 & 30.8 & 66.9 & 52.0 & 33.7 & 8.5 & 91.2 & 19.9 & 5.4 & 92.8 \\
\hline 1992 & 30.1 & 66.1 & 52.4 & 33.7 & 8.8 & 90.0 & 20.6 & 5.2 & 92.3 \\
\hline 1993 & 30.7 & 66.4 & 52.3 & 35.3 & 9.1 & 87.4 & 22.6 & 5.2 & 90.4 \\
\hline 1994 & 28.2 & 69.5 & 49.8 & 39.5 & 10.6 & 84.1 & 26.1 & 6.9 & 86.7 \\
\hline 1995 & 24.6 & 71.3 & 47.8 & 40.4 & 10.7 & 85.2 & 31.7 & 8.7 & 84.2 \\
\hline 1996 & 22.9 & 73.1 & 47.3 & 43.2 & 12.2 & 85.5 & 32.0 & 9.0 & 87.0 \\
\hline 1997 & 19.2 & 75.4 & 47.2 & 49.2 & 13.9 & 85.1 & 36.7 & 11.0 & 85.4 \\
\hline
\end{tabular}


Figure 1: AFDC Budget Constraint

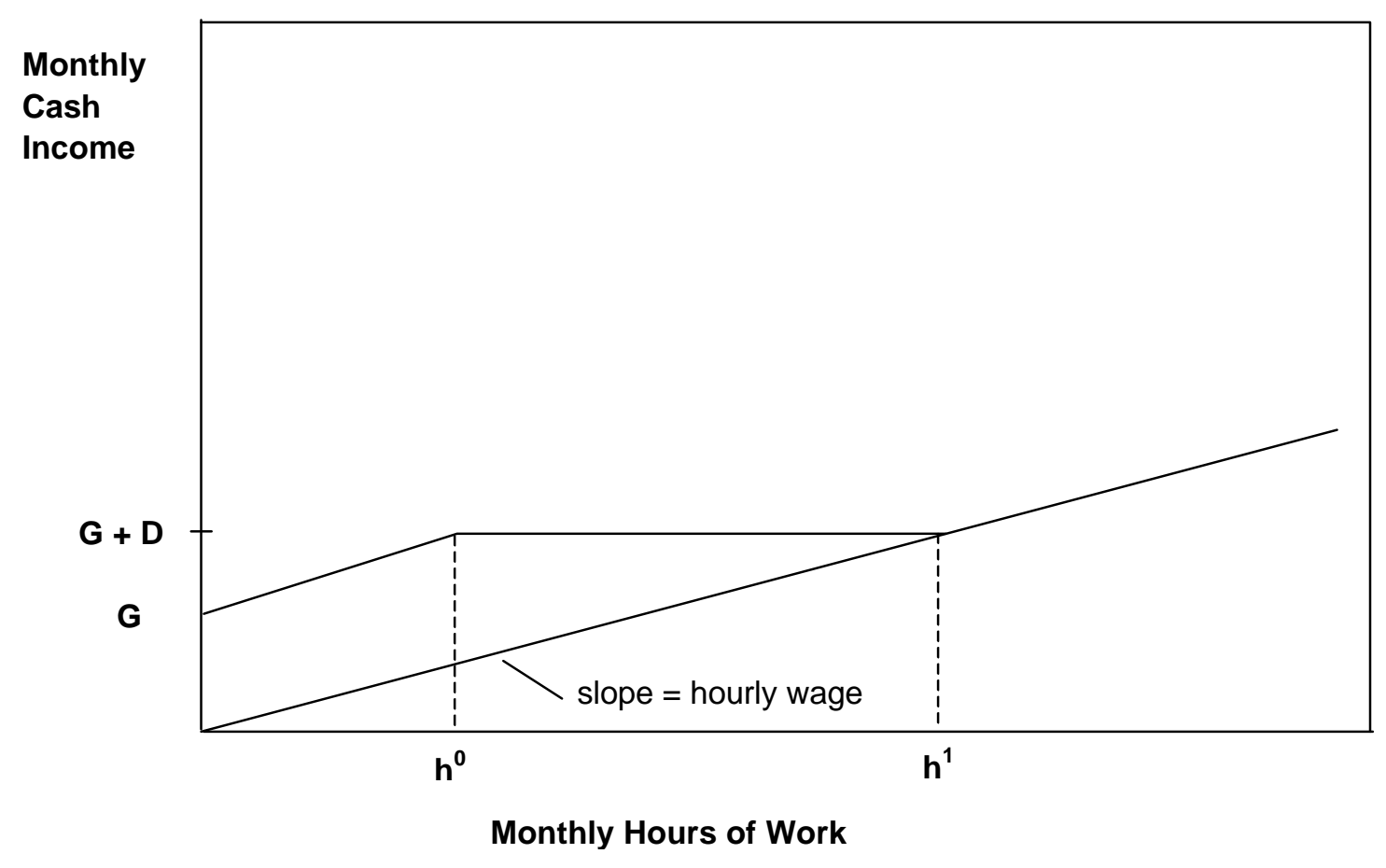


Figure 2: Financial Incentives

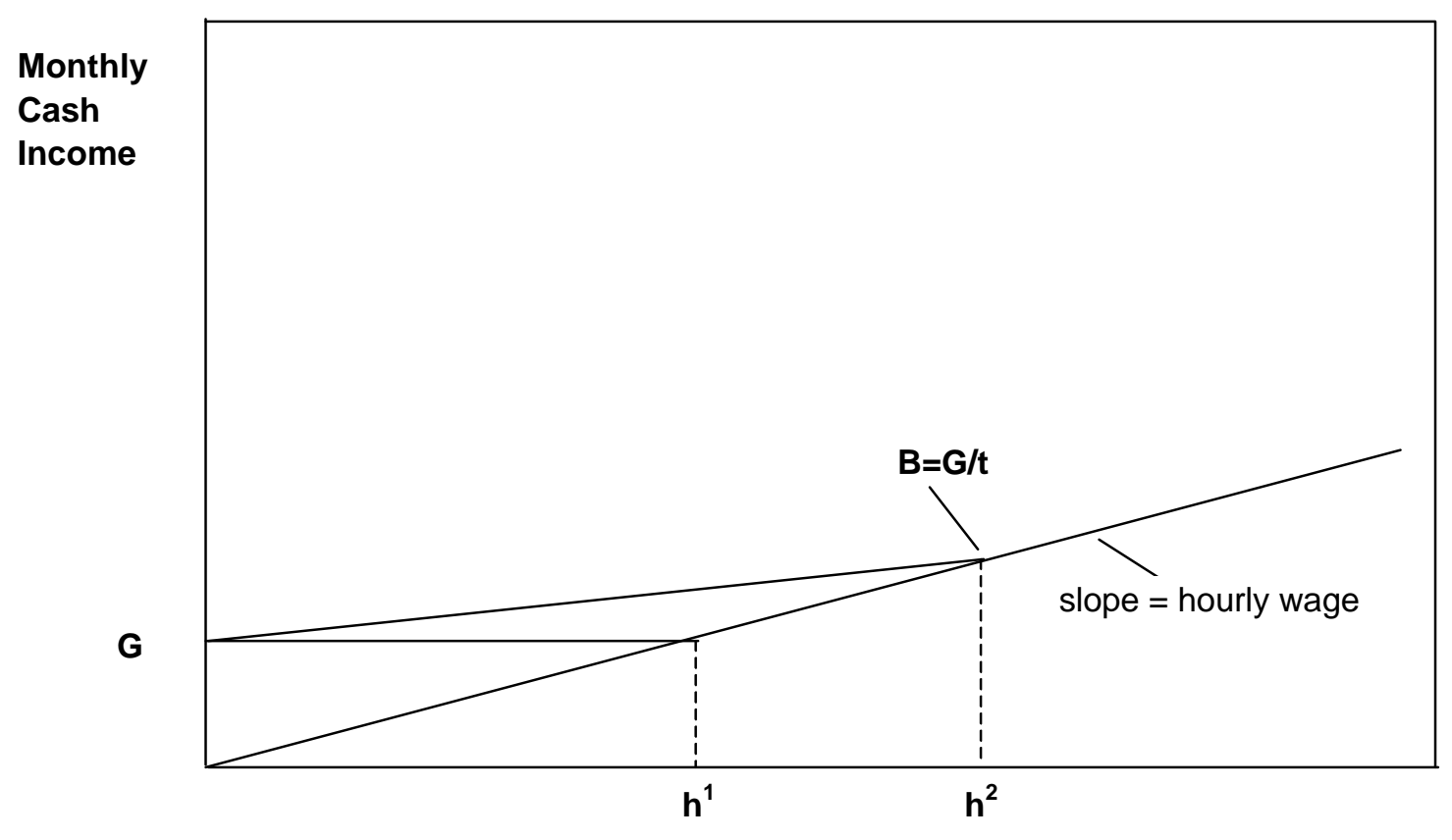

Monthly Hours of Work 
Figure 3: Hours-Limited Incentives

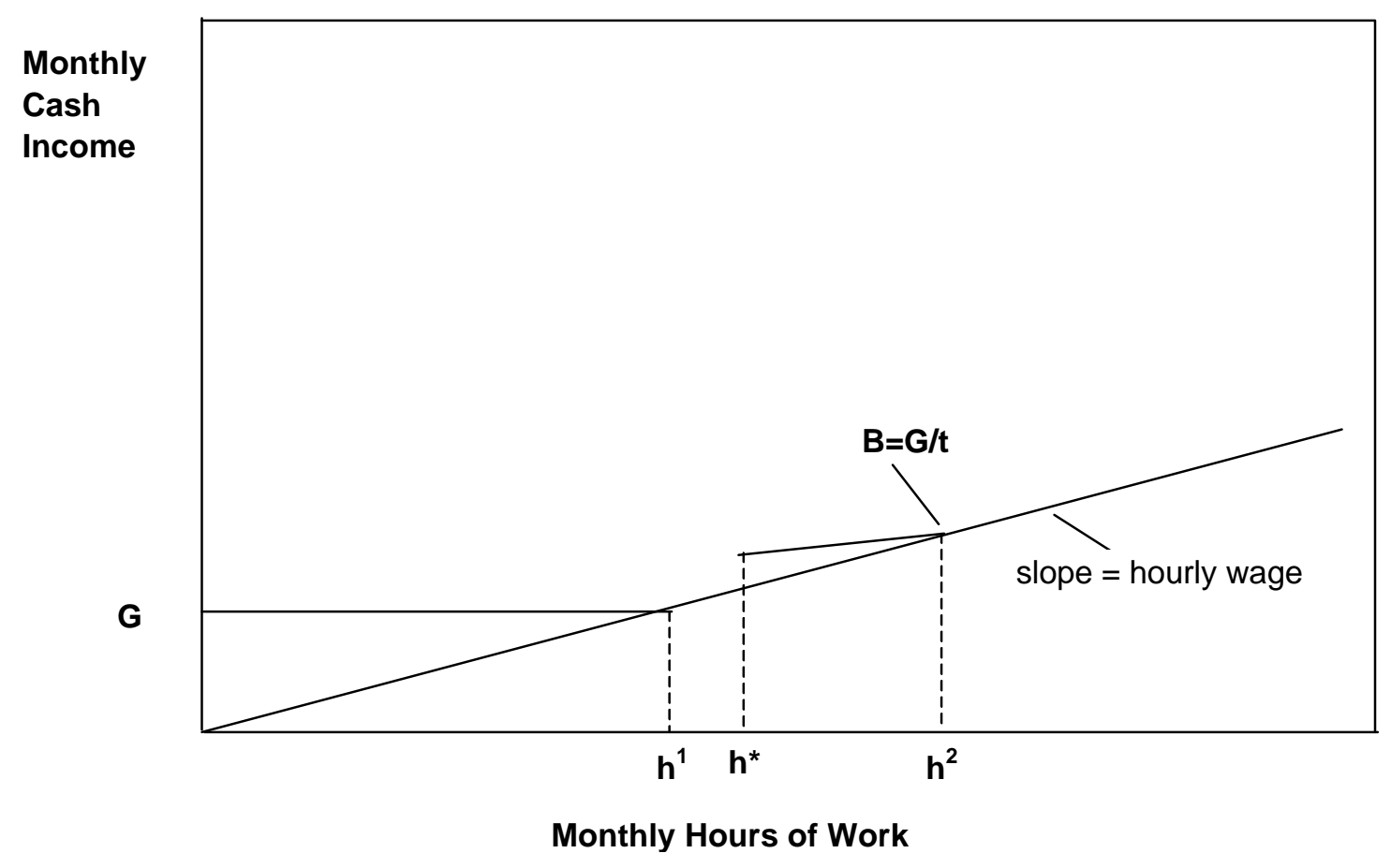


Figure 4: Annual Income Under Welfare and MFIP Wage Rate $=\$ 5$ Per Hour

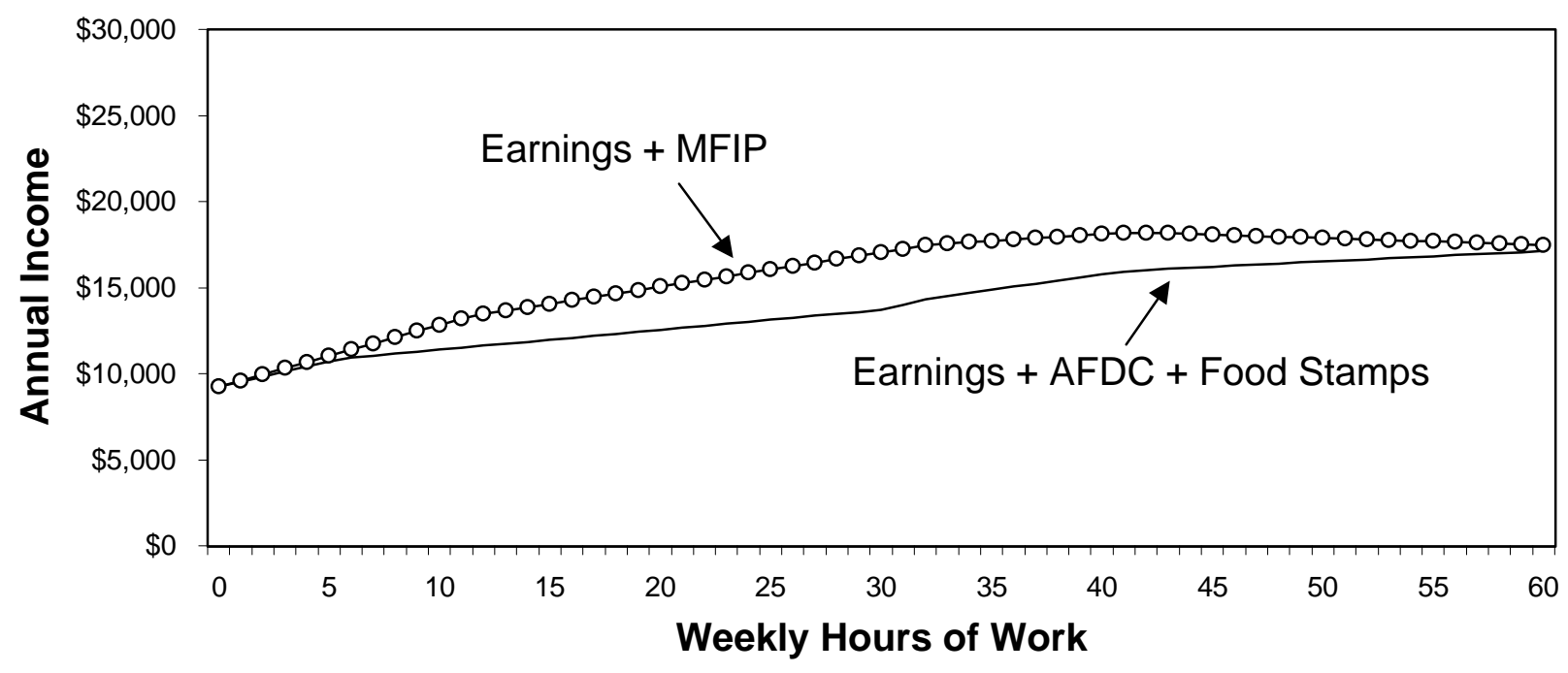


Figure 5a: Annual Income Under Income Assistance and SSP Wage Rate $=\$ 5$ Per Hour, New Brunswick

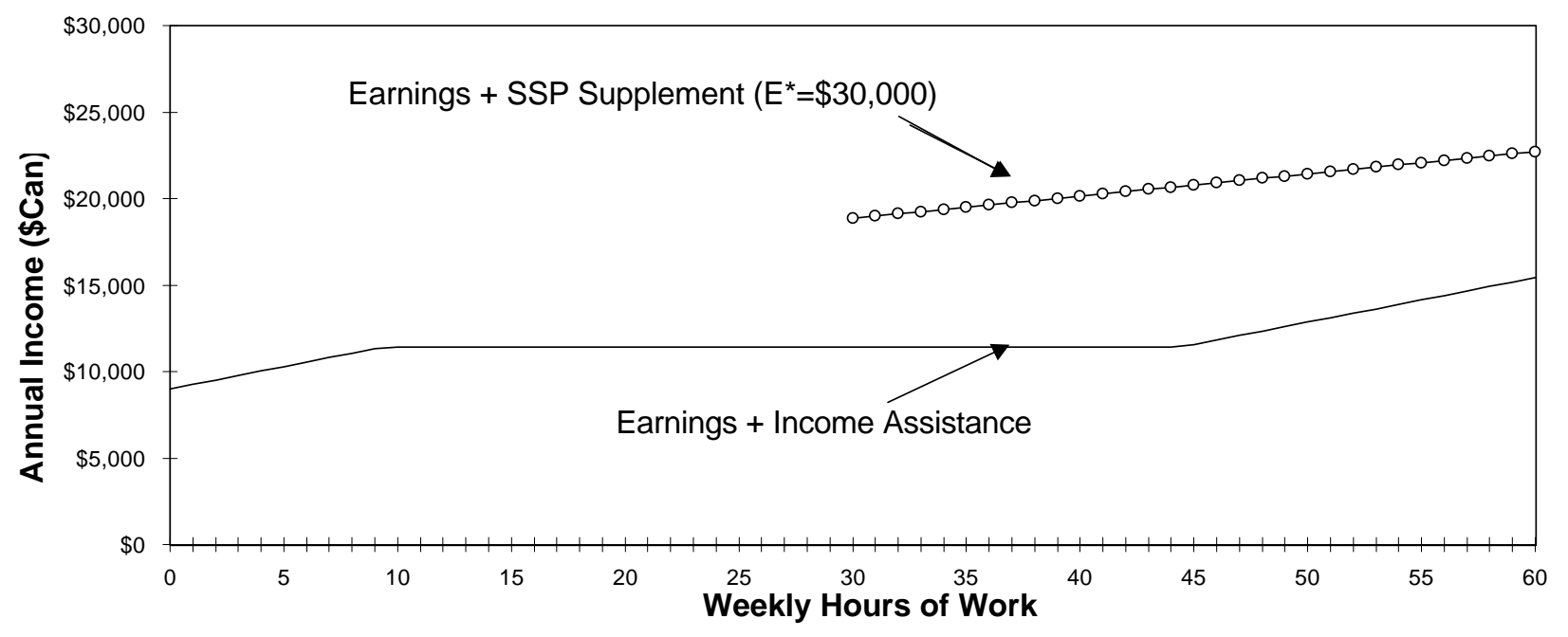

Figure 5b: Annual Income With and Without New Hope Benefits Wage Rate $=\$ 5$ Per Hour

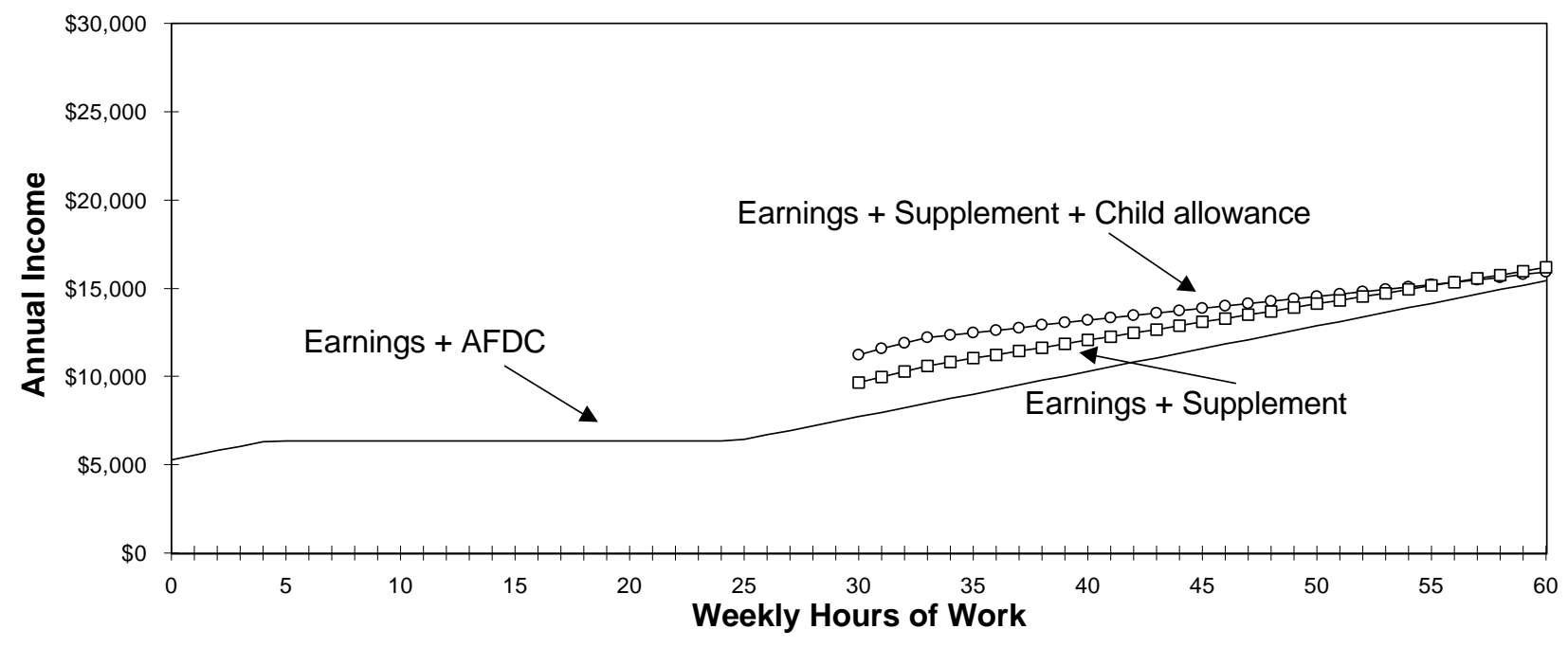


Figure 6a: Annual Income Under AFDC and CAP Single Parent With Two Children, Wage Rate $=\$ 5$ Per Hour Monroe County, New York

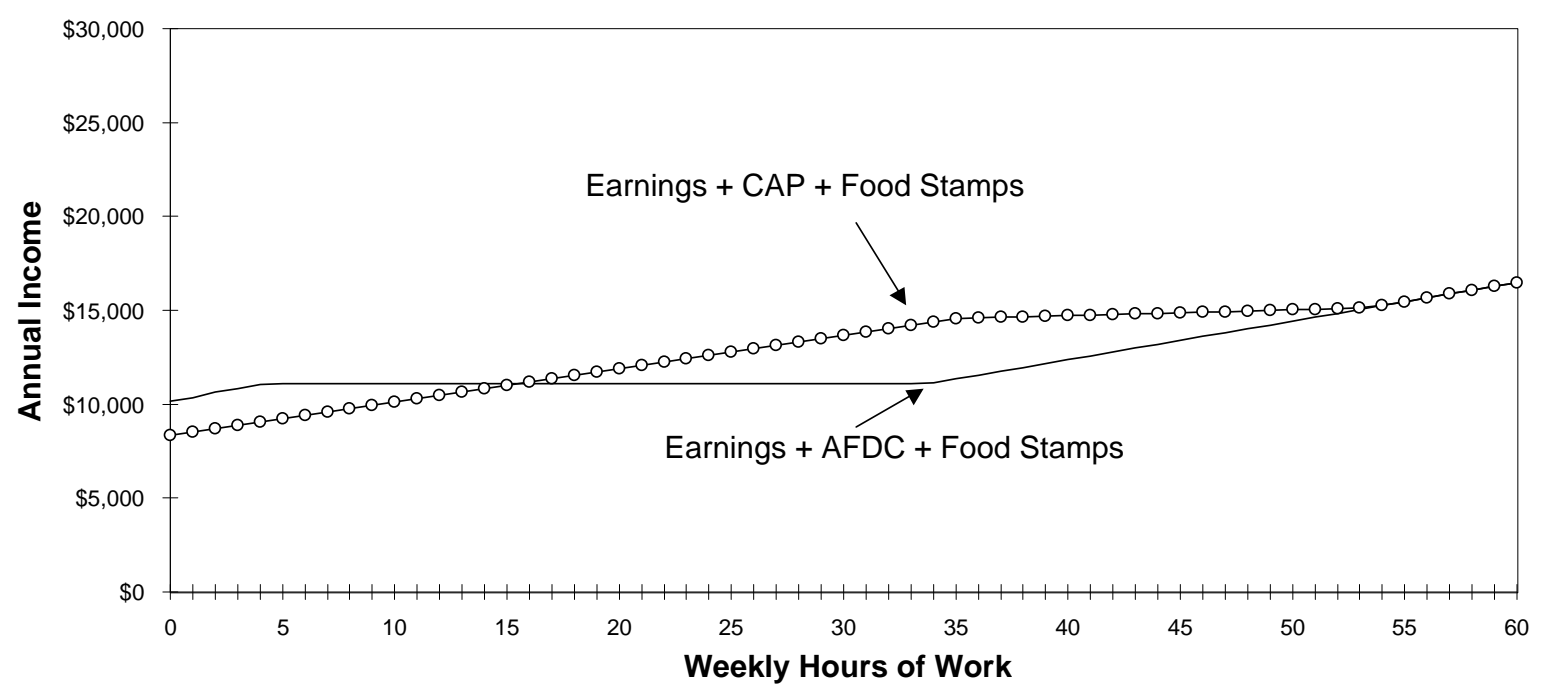

Figure 6b: Annual Income Under AFDC and CAP Single Parent With Two Children, Wage Rate $=\$ 7$ Per Hour Monroe County, New York

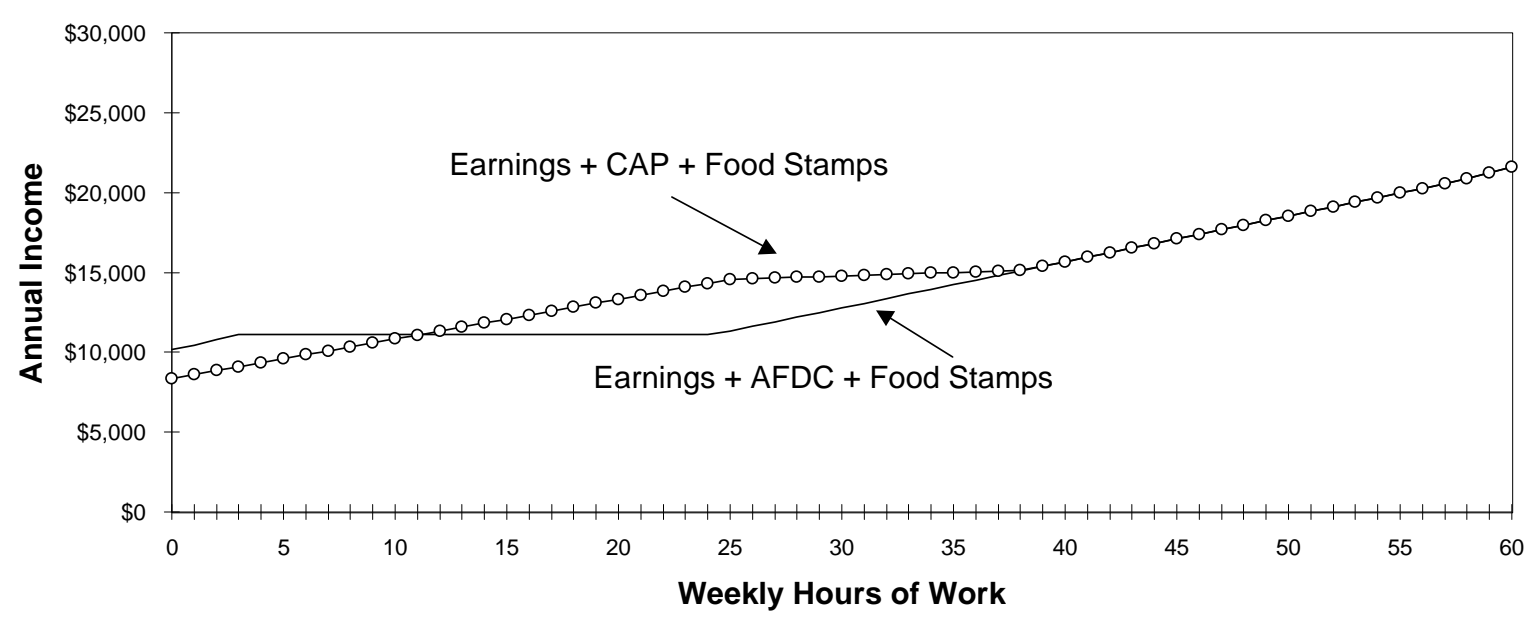


Figure 7a: Annual Income With and Without EITC

Welfare Guarantee $=\$ 400$ Per Month, Wage Rate $=\$ 5.15$ Per Hour

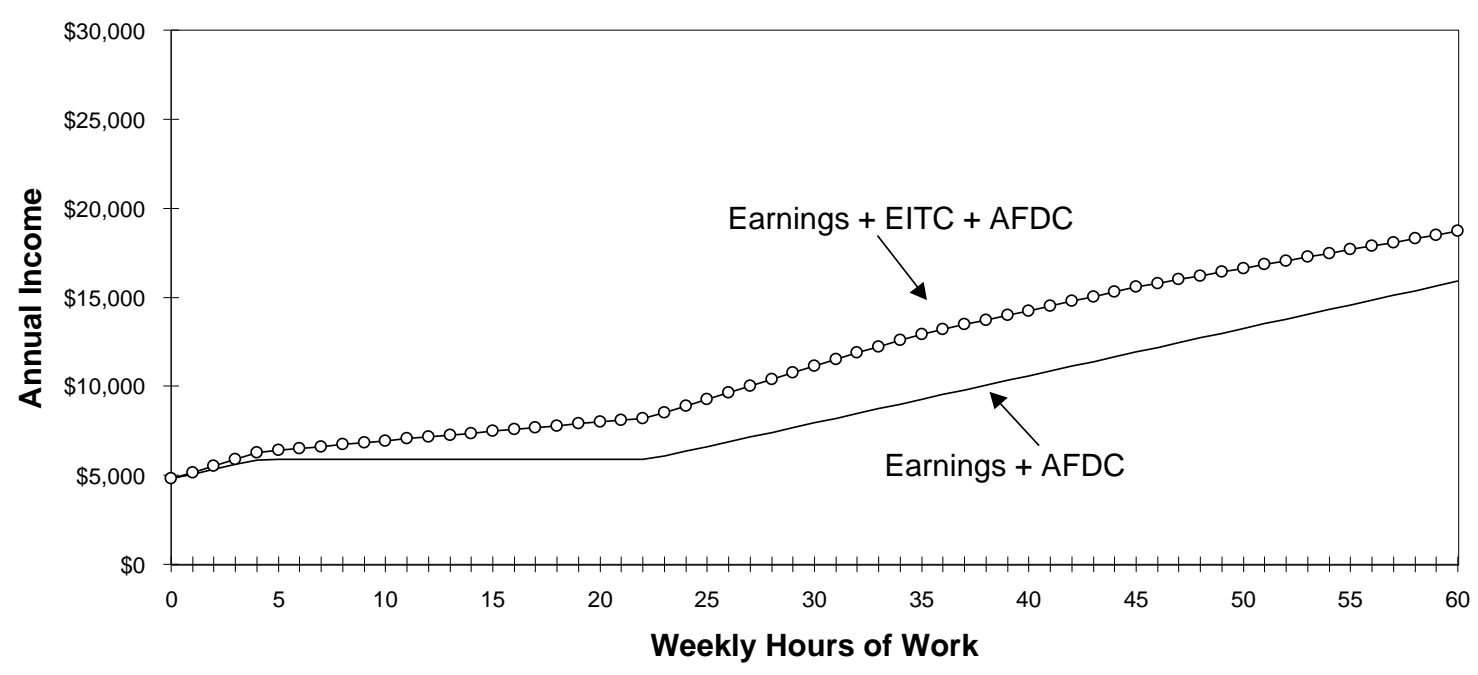

Figure 7b: Annual Income With and Without EITC

Welfare Guarantee $=\$ 400$ Per Month, Wage Rate $=\$ 8.00$ Per Hour

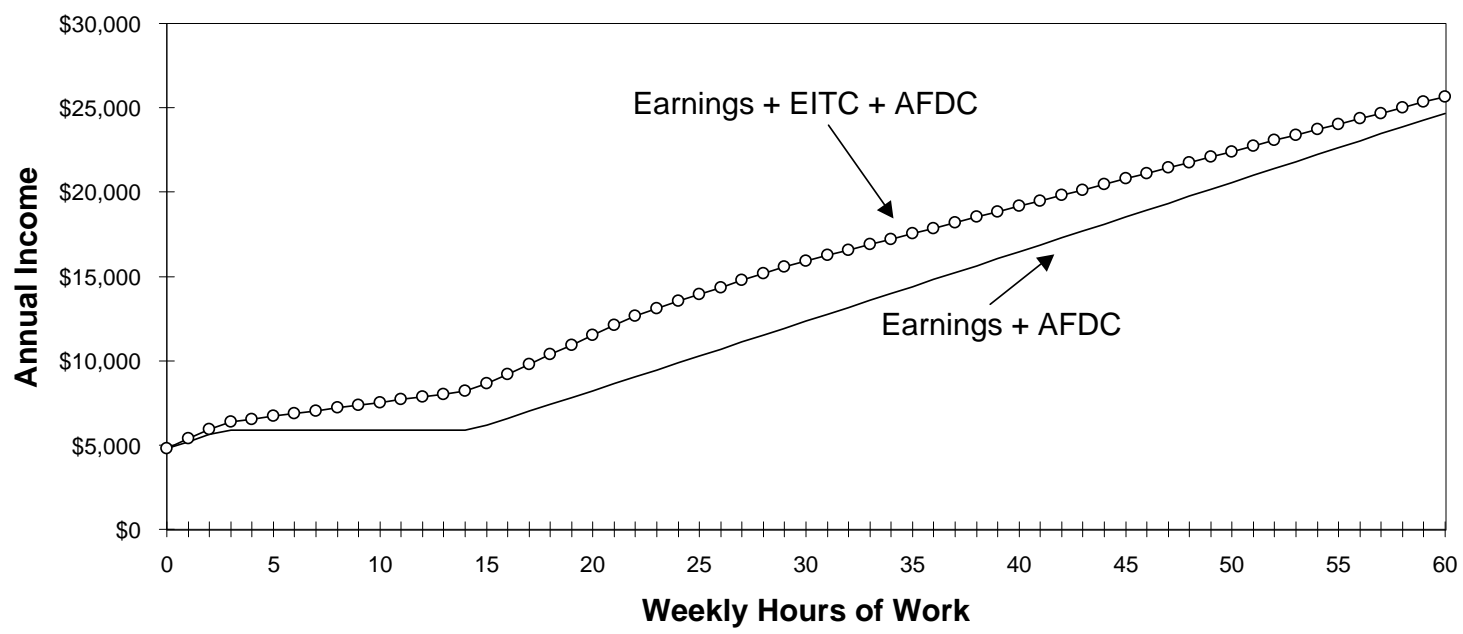


Figure 8: Average Annual Weeks of Work of Women, March CPS Data

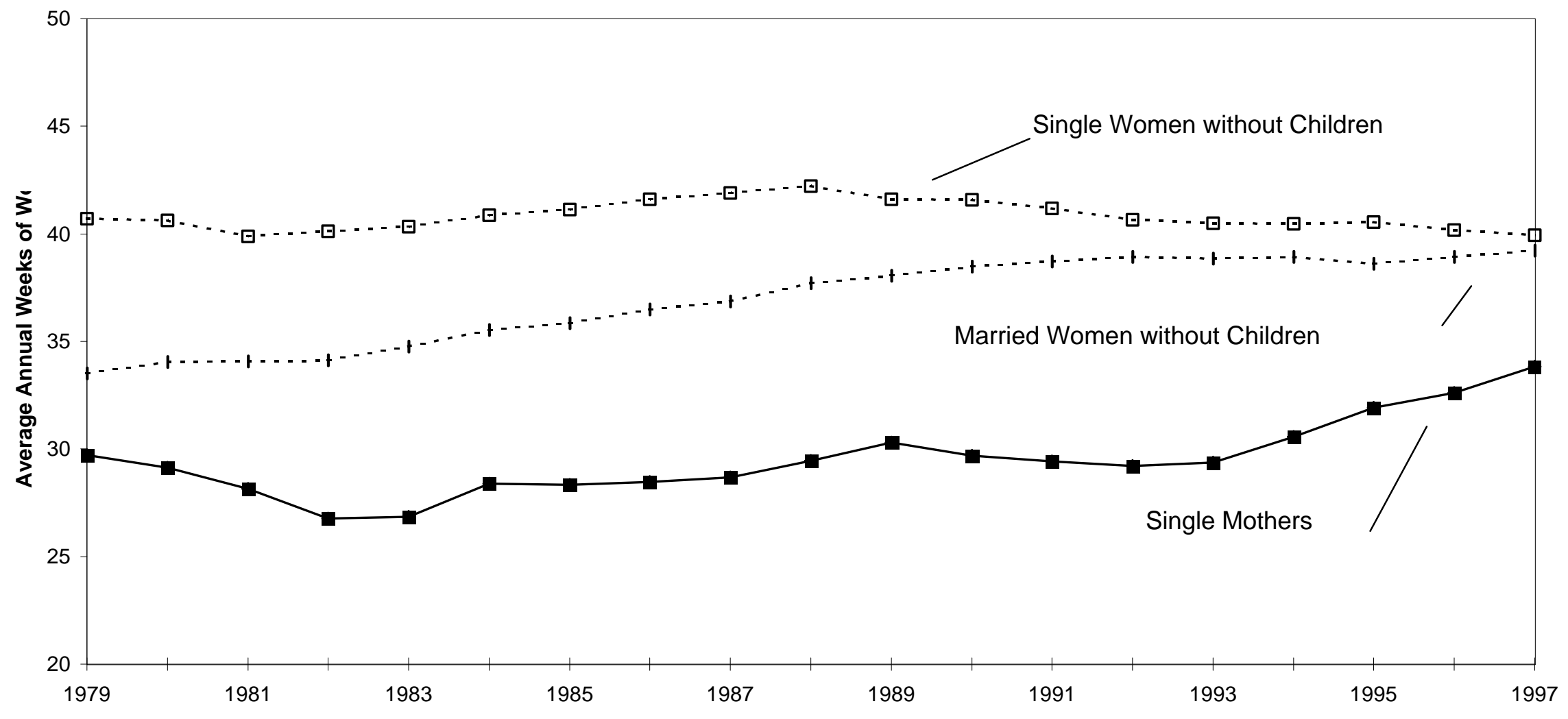

